\title{
A new Oligocene relative of the Caproidae (Teleostei: Acanthopterygii) from the Outer Carpathians, Poland
}

\author{
MAtGORZATA BIEŃKOWSKA-WASILUK \& NIELS BONDE
}

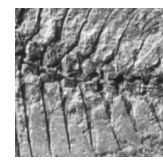

\begin{abstract}
The osteology of Caprosimilis carpathicus gen. et sp. nov., from the Early Oligocene Menilite beds of the Outer Carpathians, Poland, is described. This taxon possesses a unique combination of features that supports its recognition as a new genus of the superorder Acanthopterygii. It is characterized by: deep body, posterior part of frontals ornamented with curving ridges and spines, eight branchiostegal rays, 24 vertebrae ( $10 \mathrm{abdominal})$, ossified ribs present on $4^{\text {th }}$ to $10^{\text {th }}$ abdominal vertebrae, nine spines and 21 soft rays in dorsal fin, four spines and 18 soft rays in anal fin, three anal-fin pterygiophores in first interhaemal space (between haemal spines of first and second caudal vertebrae), three supernumerary spines on first radial of anal fin. Caprosimilis carpathicus gen. et sp. nov. is compared with extant genera of Caproidae (Antigonia and Capros), Zeiformes (Cyttus and Oreosoma) and Tetraodontiformes (Parahollardia), and with the Early Eocene genera Protozeus, Acanthonemus and Zorzinichthys to access its phylogenetic position. A phylogenetic analysis indicates that $C$. carpathicus gen. et sp. nov. is a close relative of the Caproidae. $\bullet$ Key words: Caprosimilis carpathicus gen. et sp. nov., Menilite beds, comparative osteology, phylogenetic analysis, zeomorpha.
\end{abstract}

BIEŃKOWSKA-WASILUK, M. \& Bonde, N. 2015. A new Oligocene relative of the Caproidae (Teleostei: Acanthopterygii) from the Outer Carpathians, Poland. Bulletin of Geosciences 90(2), 461-478 (11 figures, 1 table, 3 online appendices). Czech Geological Survey, Prague. ISSN 1214-1119. Manuscript received May 28, 2014; accepted in revised form February 16, 2015; published online March 16, 2015; issued March 23, 2015.

\begin{abstract}
Matgorzata Bieńkowska-Wasiluk (corresponding author), Faculty of Geology, University of Warsaw, Żwirki i Wigury 93, 02-089 Warszawa, Poland; m.wasiluk@uw.edu.pl•Niels Bonde, Zoological Museum (SNM), Universitetsparken 15, DK-2100 Copenhagen Ø, Denmark, and Fur Museum (Muserum Salling), Nederby, DK-7884 Fur, Denmark; niels.bonde@mail.tele.dk,nielsb.pal@gmail.com
\end{abstract}

The earliest boarfishes (Caproidae) are known from the Early Eocene and are represented by a well-preserved skeleton of Eoantigonia (Sorbini 1983, Sorbini \& Bottura 1988, Baciu et al. 2005b; for age see Medizza 1975, Papazzoni \& Trevisani 2006) and an otolith of Antigonia taxon (Nolf \& Tyler 2006). In the Oligocene-Miocene, caproids comprise three genera: Antigonia, Capros, and Proantigonia (Baciu et al. 2005b), of which the former two are extant. In the Early Eocene there are four extinct genera closely related to caproids: Acanthonemus (Blainville 1818, Blot 1969), Sorbiniperca (Tyler 1998), Sorbinicapros (Bannikov \& Tyler 1999), and Zorzinichthys (Tyler \& Bannikov 2002).

We describe Caprosimilis carpathicus gen. et sp. nov. from the Lower Oligocene Menilite beds of the Outer Carpathians, of the superorder Acanthopterygii, as a close relative to caproids. To access its phylogenetic position, we compare Caprosimilis with the following taxa: the Early Eocene Protozeus (Bonde \& Tyler in Tyler et al. 2000; Baciu et al. 2005c, pp. 124-126; illustrated Bonde 1987, p. 39; Bonde et al. 2008, p. 98); two Recent genera of zeiforms, Cyttus and Oreosoma; the Recent tetraodontiform
Parahollardia; the Recent caproids Antigonia and Capros; and the Early Eocene Acanthonemus and Zorzinichthys. Acanthopterygii, or spiny-rayed fishes, are a large group, with more than 250 families (Nelson 2006). There is still disagreement about relationstips of caproids, tetraodontiforms, zeiforms, and their close relatives that are known only from fossils, such as Acanthonemus, Sorbiniperca, Sorbinicapros and Zorzinichthys. In the morphological analysis by Rosen (1984) caproids, tetraodontiforms, and zeiforms formed a clade, with caproids as the sister-group to tetraodontiforms and zeiforms. In two comprehensive morphological studies of acanthopterygians (Stiassny \& Moore 1992, Johnson \& Patterson 1993), caproids and tetraodontiforms were placed within the Percomorpha, while zeiforms were considered as more basal Acanthopterygii.

Tyler et al. (2003) presented a comprehensive phylogenetic analysis based on morphological characters of the interrelationships of extant caproids, zeiforms, and tetraodontiforms. Tyler et al. (2003) found support for a clade of those three taxons in three of their four analyses, but it was not supported in the other. Tyler \& Santini 


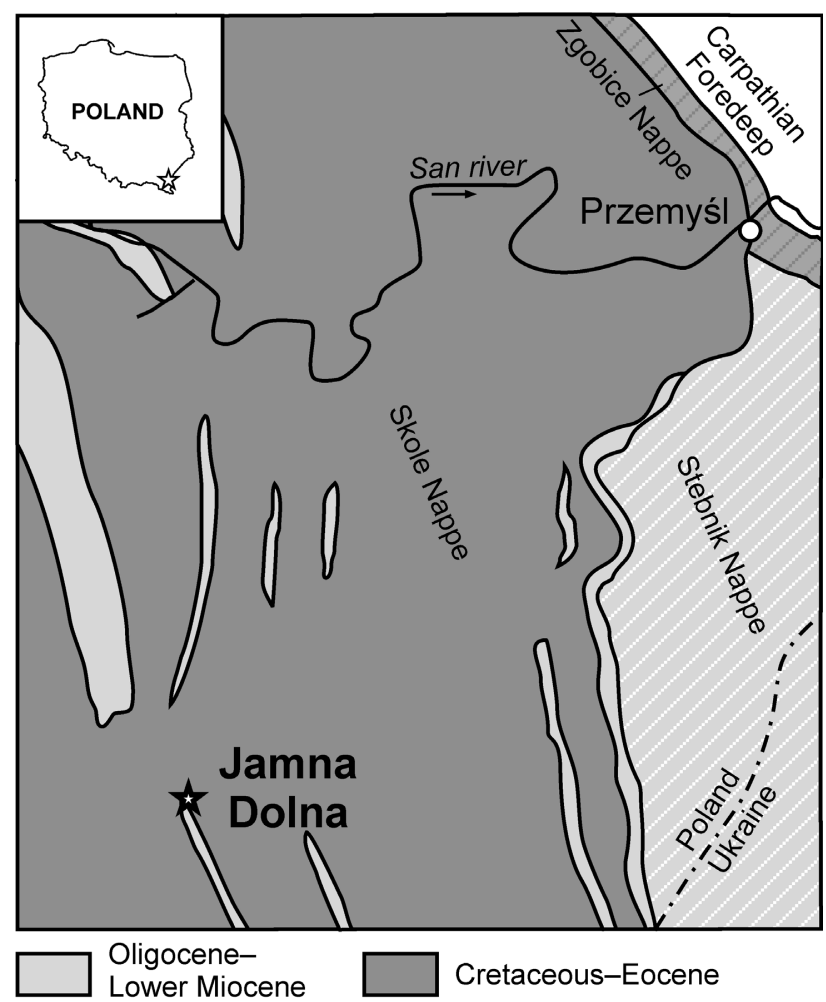

Figure 1. Location of Jamna Dolna site, where Caprosimilis carpathicus gen. et sp. nov. was collected (adopted from Kotlarczyk et al. 2006).

(2005) expanded this analysis by including extinct genera of zeiforms and their presumed close relatives of Cretaceous to Eocene age. Tyler \& Santini (2005) in the majority rule consensus analysis confirmed the presence of a clade formed by Caproidae, Tetraodontiformes, and Zeiformes; this being the zeomorph clade. Caproids were represented by the two extant genera Capros and Antigonia and the Eocene genus Eoantigonia (in Tyler \& Santini 2005 as Antigonia veronensis, in the process of being referred by Baciu et al. 2005b to Eoantigonia gen. nov.). Tetraodontiformes were represented by the extant Parahollardia (Triacanthodidae) and Pseudotriacanthus (Triacanthidae), the two most basal extant clades of the order. The Zeiformes in Tyler et al. (2003) were represented by 16 extant genera. Six families of Zeiformes were recognized as a monophyletic group in this analysis. Among them Cyttus (Cyttidae) was the most primitive taxon as a sistergroup to the other five families. The family Oreosomatidae was the second most primitive taxon as a sistergroup to the remaining four families (Tyler et al. 2003, p. 35). In an alternative analysis by Tyler \& Santini (2005, fig. 9; strict consensus of two equally parsimonious trees from reduced data set of 25 fossil and extant taxa after exclusion of most non-zeiform taxa), that included fossil taxa, Cyttidae and Oreosomatidae formed a sistergroup to the four other families of zeiforms. The genus Protozeus (Early Eocene, Den- mark) was indicated as a primitive zeiform by Tyler et al. (2000) and Tyler \& Santini (2005). We herein compared Caprosimilis carpathicus gen. et sp. nov. with Cyttus and Oreosoma, assuming they represent the most primitive of the living zeiforms.

In Tyler \& Santini (2005), Parahollardia (Tetraodontiformes) was recognized as the sistergroup of zeiforms, whereas caproids were the sistergroup of tetraodontiforms plus zeiforms. Zorzinichthys annae Tyler \& Bannikov 2002, Sorbiniperca scheuchzeri Tyler 1998, and Sorbinicapros sorbiniorum Bannikov \& Tyler 1999 (all Early Eocene, ca $50 \mathrm{Ma}$, Monte Bolca) formed a clade of the two extinct families, the Sorbinipercidae and Zorzinichthyidae (see Tyler \& Santini 2005, p. 166). This clade was considered as a sistergroup to the tetraodontiforms. The genus Acanthonemus (Early Eocene, Monte Bolca), which Bannikov (1991) referred to the new family Acanthonemidae, was in an outgroup position to the Caproidae, and in a sistergroup position to the clade formed by Caproidae, Tetraodontiformes, and Zeiformes (Tyler \& Santini 2005, p. 166).

Some molecular analyses, based on full mitochondrial genomes, or a combination of mitochondrial and nuclear genes, place zeiforms as the sistergroup to gadiforms as one of the most basal lineages of Acanthomorpha, while tetraodontiforms and caproids are fairly closely related to one another, or are even sistergroups within Percomorpha (Chen et al. 2003, Miya et al. 2003, Dettaï \& Lecointre 2008, Li et al. 2009, Grande et al. 2013, Near et al. 2013). Position of caproids within Percomorpha is still not clear in such analyses, neither in the morphological analyses (see Wiley \& Johnson 2010). Absence of clade formed by Caproidae, Tetraodontiformes, and Zeiformes in molecular analyses can indicate that morphological characters supposed as synapomorphies by Tyler et al. (2003) are in stead evidence of convergence. First of those is neural spine closely applied to skull. Grande et al. (2013) proposed as potential synapomorphy "association of first neural arch and spine with neurocranium" for Gadiformes, Stylephorus and Zeiformes. Second convergence is first pterygiophore of the spiny dorsal fin, inserted in the first interneural space, i.e. between the first and second neural spines, or into what would be the preneural space if the first neural arch and spine were not plastered onto the skull, and often slanted forward. Third convergence is the anterior end of epihyal is distinctly less deep than the adjacent part of the ceratohyal. At present, our morphology-based analysis cannot be compared to the results of the molecular analyses because for many taxa present in the latter we do not have applicable morphological data for our data set. Conversely, several of our taxa are absent in the molecular analyses. We believe that there is a need for a more comprehensive morphological analysis that would include extant and extinct Gadiformes and Perciformes that appear to 
be close relatives of caproids, tetraodontiforms and zeiforms. Such analysis should hopefully allow to test for congruence among morphological and molecular analyses. Although molecular analyses show that caproids are not closely related to zeiforms in our opinion morphological comparisons of the new species with zeiforms, caproids and tetraodontiforms are significant, because those taxa have high level of similarity in body shape, osteological morphology and meristic characters.

\section{Geological setting}

The specimen described herein was recovered from an outcrop of the Early Oligocene Menilite beds (also referred to as Menilite formation) in the Skole Nappe (Silesian Unit) of Outer (Flysch) Carpathians (Fig. 1). The outcrop is located $20 \mathrm{~km}$ south-west of Przemyśl, southern Poland, in the area of the former village of Jamna Dolna, $c a 8$ $\mathrm{km}$ southeast of Bircza, about $1 \mathrm{~km}$ south of a bridge over the river Wiar at Trójca, in the upper part of the escarpment of the river Jamninka (right tributary of the river Wiar). It is an exposure approximately $70 \mathrm{~m}$ long and $7 \mathrm{~m}$ high. The locality has been known since 1953 (Jerzmańska 1968, Jerzmańska \& Kotlarczyk 1968, $\mathrm{J}_{\mathrm{AC}}$ and $\mathrm{J}_{\mathrm{DG}}$ in Kotlarczyk et al. 2006).

The Menilite beds are more than $70 \mathrm{~m}$ thick in this area, and their upper boundary is tectonical in the region of Jamna Dolna-Łodzinka. Generally in this area of the Outer Carpathians their upper boundary is of Early Miocene age (Kotlarczyk et al. 2006). The specimen of Caprosimilis carpathicus gen. et sp. nov. comes from a $31.0 \pm 1.0 \mathrm{Ma}$ (Kotlarczyk et al. 2006) shales belonging to the lower part of the Menilite beds, the Rudawka Tractionite member, lithological unit F-G (Fig. 2) of Jerzmańska \& Kotlarczyk (1968), ichthyofaunal zone IPM2 (Glossanodon musceli and Palaeogadus simonescui, Kotlarczyk et al. 2006, p. 66, tab. 26) above ichthyofaunal subzone IPM2-T.suB. (Trachinus event).

The Menilite beds are renowned for their richness of fossils, of epi- and mesopelagic as well as some benthopelagic and neritic fishes (Kotlarczyk et al. 2006, Bieńkowska-Wasiluk 2010). The lithological units F and G yielded well-preserved teleost fishes of the families Clupeidae, Argentinidae, Merlucciidae, Trichiuridae, and Scombridae (Kotlarczyk et al. 2006). Clupeids and scombrids are epipelagic fishes, merlucciids and trichiurids live in deep parts of the pelagic zone and also above continental slopes or submarine ridges and benthicly below the continental shelf.

Shales with Caprosimilis carpathicus gen. et sp. nov. were deposited in the Carpathian Basin of the Paratethys. They are the result of pelagic sedimentation in the basin that was associated with distal turbidites.

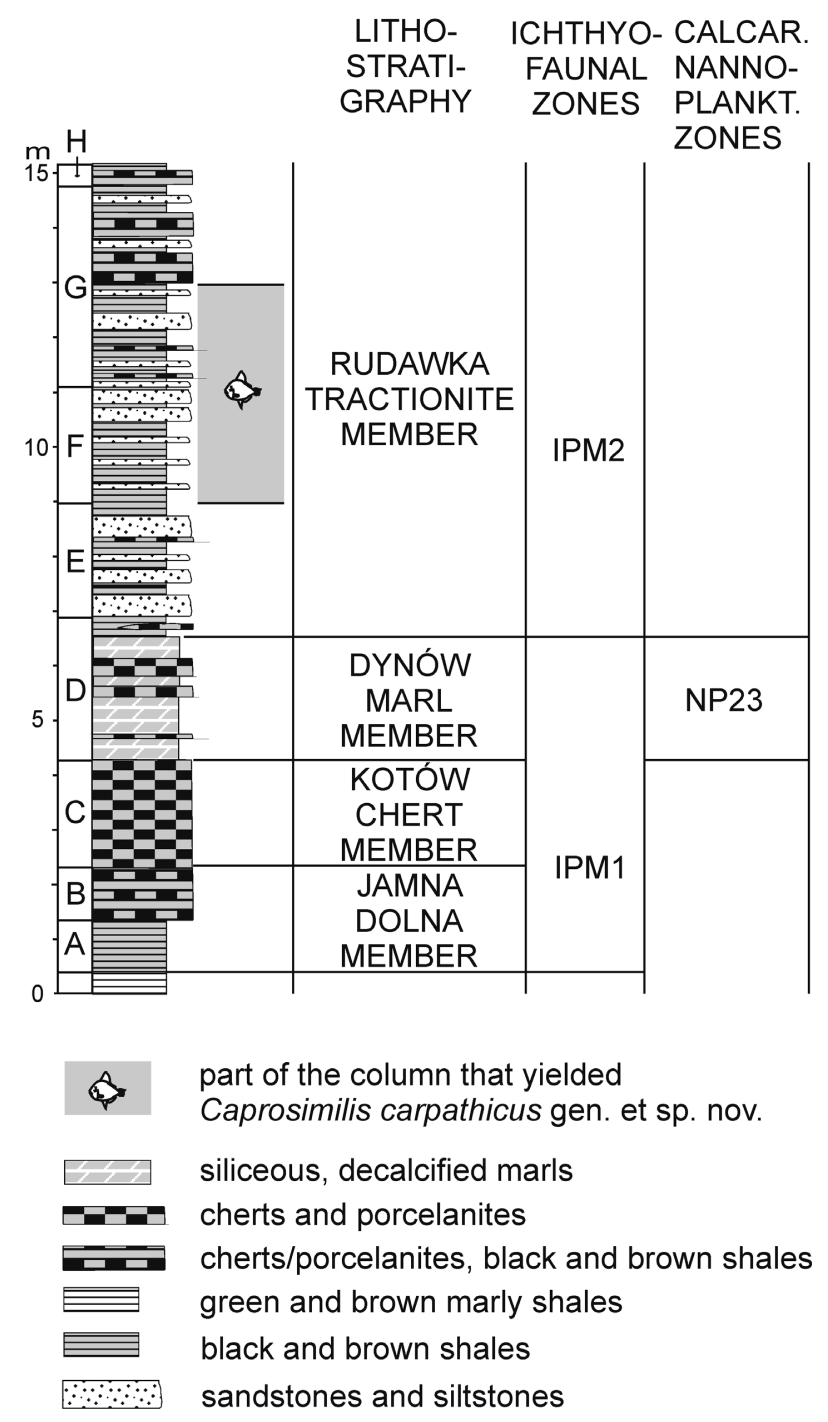

Figure 2. Position of Caprosimilis carpathicus gen. et sp. nov. in the lithologic column of the Menilite beds at Jamna Dolna correlated with the lithostratigraphy, ichthyofaunal, and calcareous nannoplankton zones (adopted from Kotlarczyk et al. 2006)

\section{Preservation of the holotype}

The specimen of Caprosimilis carpathicus gen. et sp. nov. is preserved as a nearly complete skeleton as imprint in left and right part. We use the term "right part" when the imprint contain mainly the morphology of the right side of the fish.

The preservation as lateral imprints of both the right and left opercle and preopercle is very good, but the other bones that were originally between them are not preserved, such as the branchial arches. It is a different situation with the lower jaw, because the lateral and the medial faces of the right lower jaw are observed on the two parts, and of the left lower jaw only the ventral edge is seen. This indicates that the sediment squeezed between the two jaw halves is still preserved in the left plate below the imprint of the 
medial face of the right lower jaw. Clearly, no other bones are preserved in this thin layer of sediment (but it could have been the case for part of the tongue). It also means that by preparing through the presently exposed imprint and removing the sediment, then the entire lateral face of the left lower jaw could be exposed.

\section{Materials and methods}

The single holotypic specimen is in the collection of the Muzeum Geologiczne im. Stanisława Józefa Thugutta at the Faculty of Geology, University of Warsaw (MWGUW). The specimen was studied using a stereomicroscope with an attached camera lucida drawing arm. The specimen required remains of bones and matrix to be removed before examination in order to investigate the shapes of bones in the skull and the presence or absence of external fin elements. This was achieved using scalpel and brush.

Comparative material examined. - Capros aper (Linnaeus, 1758), Recent, Zoological Museum, University of Copenhagen, Denmark. Antigonia capros Lowe, 1843, Recent, National Museum of Natural History, New York and Washington D.C. Protozeus kuehnei Bonde \& Tyler in Tyler et al., 2000, Early Eocene, DK 217, Geological Museum, University of Copenhagen, Denmark. Eoantigonia veronensis (Sorbini, 1983), Early Eocene, T.924, Museo Civico di Storia Naturale di Verona (MCSNV), Italy. Zorzinichthys annae Tyler \& Bannikov, 2002, Early Eocene, T.289, I.G.24486, MCSNV, Italy. Acanthonemus subaureus (Blainville, 1818), Early Eocene, T.147, T.148, T.305, T.987/988, VD.108-109, T.446, I.G.23690 and I.G.129658/129659, MCSNV, Italy.

Anatomical abbreviations. - aop - articulation of the opercle with hyomandibula; br - branchiostegal rays; bs - basisphenoid; chy - anterior ceratohyal (distal); cl - cleithrum; co - coracoid; cr - crest; d - dentary; da dermarticular; dsp - dermosphenotic; ecp - ectopterygoid; ehy - "epihyal" - posterior ceratohyal; en - epineural; eoc-exoccipital; ep - epural; ept - endopterygoid; ex - extrascapular; fr - frontal; hhy - hypohyal; hp - hypural; hpu - haemal spine of preural vertebra; hy - hyomandibula; ih - interhaemal space; in - interneural space; io - infraorbital; 1. - left; lfp -lateral flanges of pelvis; la - lachrymal - first infraorbital; leth - lateral ethmoid; meth - mesethmoid; m.p. - median pore; mpt - metapterygoid; mx - maxilla; na - nasal; nsp - neural spine; op - opercle; pa - parietal; pcl - postcleithrum; ph - parhypural; pl - palatinum; pmx - premaxilla; po - prootic; pop - preopercle; $\mathrm{ppp}$ - postpelvic process; $\mathrm{pr}$ - procurrent caudal ray; ps - parasphenoid; pt - posttemporal; pto - pterotic; pts - pterosphenoid; pu - preural centrum/vertebra;
P - pectoral fin; q - quadrate; $\mathrm{r}$ - principal caudal ray; r. - right; ra - retroarticular; sc - scapula; s.c. - sensory canal; scl - supracleithrum; soc - supraoccipital; sop - subopercle; sp - spine; ssp - supernumerary spine; st - supratemporal; sy - symplectic; u - ural centrum; uhy - urohyal; un - uroneural; us - urostyle; v - vertebra; Vsp - ventral fin spine.

Supporting information. - Additional Supporting Information may be found in the online version of this article.

\section{Systematic palaeontology}

Subdivision Teleostei sensu Patterson \& Rosen, 1977 Superorder Acanthopterygii Greenwood et al. 1966 Series, order and family incertae sedis

\section{Genus Caprosimilis gen. nov.}

Type species. - Caprosimilis carpathicus sp. nov., only known species, Menilite beds, Early Oligocene, Outer Carpathians, Poland.

Etymology. - After the Latin similis and genus Capros Lacépéde, because the fish in general looks similar to species of this genus.

Diagnosis. - As for the species.

\section{Caprosimilis carpathicus sp. nov.}

Figures 3-9

Holotype. - MWGUW ZI/57/013/a and b, left and right part, nearly complete fish of $16.6 \mathrm{~mm}$ standard length (SL).

Type locality and horizon. - Jamna Dolna 2 locality, Outer Carpathians, Poland, Rupelian, Early Oligocene, NP23 calcareous nannoplankton Biozone, IPM 2 ichthyofaunal zone, Rudawka Tractionite Member of the Menilite beds (Kotlarczyk et al. 2006).

Etymology. - After the geographic mountain range, the Carpathians.

Diagnosis. - Body deep, posterior part of frontals ornamented with curving ridges and spines, eight branchiostegal rays, 24 vertebrae (10 abdominal), $6^{\text {th }}$ interneural space is vacant, ossified ribs present on $4^{\text {th }}$ to $10^{\text {th }}$ abdominal vertebrae, nine spines and 21 soft rays in dorsal fin, four spines and 18 or more soft rays in anal fin, three anal-fin pterygiophores in the first interhaemal space (between the haemal spines of the first and second caudal vertebrae), three supernumerary spines on first radial of anal fin, hypurals 1-3 
free and separate from the urostylar centrum, hypural 4 a separate plate, more dorsally positioned hypurals not fused to the urostylar centrum.

Measurements. - SL (standard length) $=16.6 \mathrm{~mm}$, length of caudal vertebral column (including caudal fin skeleton) $=7 \mathrm{~mm}$, length of abdominal vertebral column $=4 \mathrm{~mm}$, maximum body depth $=9 \mathrm{~mm}$, head length $=c a 6.5 \mathrm{~mm}$ (jaws protruded $7.5 \mathrm{~mm}$ ), head depth $=7.5 \mathrm{~mm}$, braincase length (basioccipital to nasal/ethmoid) $=6 \mathrm{~mm}$, braincase height (supraoccipital to parasphenoid) $=4 \mathrm{~mm}$, orbit diameter $=3 \mathrm{~mm}$, snout length maximum extended $=3 \mathrm{~mm}$ (relaxed ca $2 \mathrm{~mm}$ ).

Description. - In the description we indicate in sqare brackets [ ] the coding of morphological characters used in subsequent phylogenetic analysis. The numbers of the characters (Appendix 1) are in general the same as in Tyler et al. (2003) and Tyler \& Santini (2005).

Skull. - The first neural arch and spine are closely applied to the skull [40-1], specifically to the exoccipital. The supraoccipital crest is triangular, high $(1 \mathrm{~mm})$, and long (ca $2 \mathrm{~mm}$ ), with a strong ridge near its anterior border; it extends anteriorly to a vertical line through the posterior part of the orbit. The frontal has a few small spines of supraocular serrations over the orbit [6-0]. The posterior part of the frontals are ornamented with curving ridges and spines (Fig. 7). The smooth bone posterior to this ornamented part of the frontals we assume to be the parietal [1-0]. The sensory canal is evident, with a wide median pore above the middle of the orbit, and widening towards the rostral end of the frontal. The nasals are subrectangular to ovaloid, with fine growth lines and the sensory canal oriented vertically. The sensory canal can be followed posteriorly along the lateral edge of the pterotic. The delimitation of the pterotic, the dermoshenotic, and the pterosphenoid cannot be determined, but we presume that the dermospenotic is fused with the sphenotic [11-1].

Posterior to the parietal on the left part (Figs 3,4) is the vertical mark of a bone that could be either the supratemporal, the dorsal branch of the posttemporal, or a single extrascapular (see Tyler et al. 2003, figs 17, 18, 40, 60, 61). On the right part (Figs 5,6), the imprint shows a different pattern; posterior to the parietal there is the oblique mark of a bone that could be either the dorsal branch of the posttemporal or the supracleithrum.

The lateral ethmoid has a strong, convex, latero-posterior edge and a ventro-medial process. The posterior part of the mesethmoid borders the antero-dorsal part of the orbit. The parasphenoid as exposed in the lower part of the orbit is straight. The basisphenoid is not of reduced size, but it is uncertain whether it is moderate to long [2-0?].

The lachrymal is large and high [8-0], with three to four very strong ventral spines and with the strong dorsal process meeting the lateral ethmoid. Infraorbitals 2-4 are relatively slender [10-0] and have no serrations. The exact limit between the individual infraorbitals is indistinct. Infraorbital 3 has a strong dorsal edge, probably indicating the presence of a subocular shelf. The most postero-dorsal infraorbital cannot be seen. There are four infraorbitals (presuming the unexposed $5^{\text {th }}$ is not subdivided) between the lachrymal and dermosphenotic [9-1]. A dorsal and lateral overhanging edge is indicated on the lachrymal and infraorbitals 2-3 and indicates the course of the sensory canal - at the front of the lachrymal there are perhaps one or two pores evident (left part). There are no "honeycomb structures" present on the lachrymal, infraorbitals, skull and opercle [5-0].

The palate is in part invisible. The jaw articulation is below the anterior margin of the orbit (below the lateral ethmoid). The quadrate is triangular, with an angle of 85 degrees at the jaw articulation. The right part shows the anterior, vertical part of the quadrate as smooth bone, and the posterior part with a more irregular surface as formed by more cancellous, endoskeletal bone. The postquadrate process and symplectic border the preopercle. The symplectic ascends to and perhaps overlaps an area of irregular surface that we assume is endoskeletal bone of the metapterygoid of uncertain shape. It does not contact the quadrate, so although we can not estimate its size, we code it as [19-1]. The lower part of the ectopterygoid is narrow, triangular, and bends slightly forward; the anterior process of this bone is partly invisible. Small parts of the palatine are present as a smooth surface between the tips of the spines of lachrymal and as the distinct, subcylindrical palatal process touching the maxilla (left part). There is no trace of either palatal or ectopterygoid teeth [16-1?, 17-1?]. The palatal articulation with the cranium is not visible [18-?]. The endopterygoid is large but of uncertain shape.

The jaws are exposed as fully protruded. The maxilla on the right part is exposed in a vertical position and has a rounded head. This head has a semi-circular, dorsal part. There is a deep imprint of a process situated between the head and the flat main shaft. It is clear that the flat part of the maxillary head and the mentioned process are articulating with the articular process of the premaxilla. The distal end of the maxilla is invisible because of the strong imprint of the dentary, but in a small area where the dentary imprint is destroyed, the distal region of the maxilla has a sharp, straight, lateral ridge near its ventral edge. The medial surface of the left maxilla can partly be seen along the ventral edge of the right maxilla. The medial side of the left premaxilla is well exposed on the right part. The ascending process of the premaxilla is more than $2 \mathrm{~mm}$ high. It is impossible to determine if there is a postmaxillary process [13-?]. There are tiny teeth in a band along the inside of the edge of left premaxilla (visible on right part). The distal 


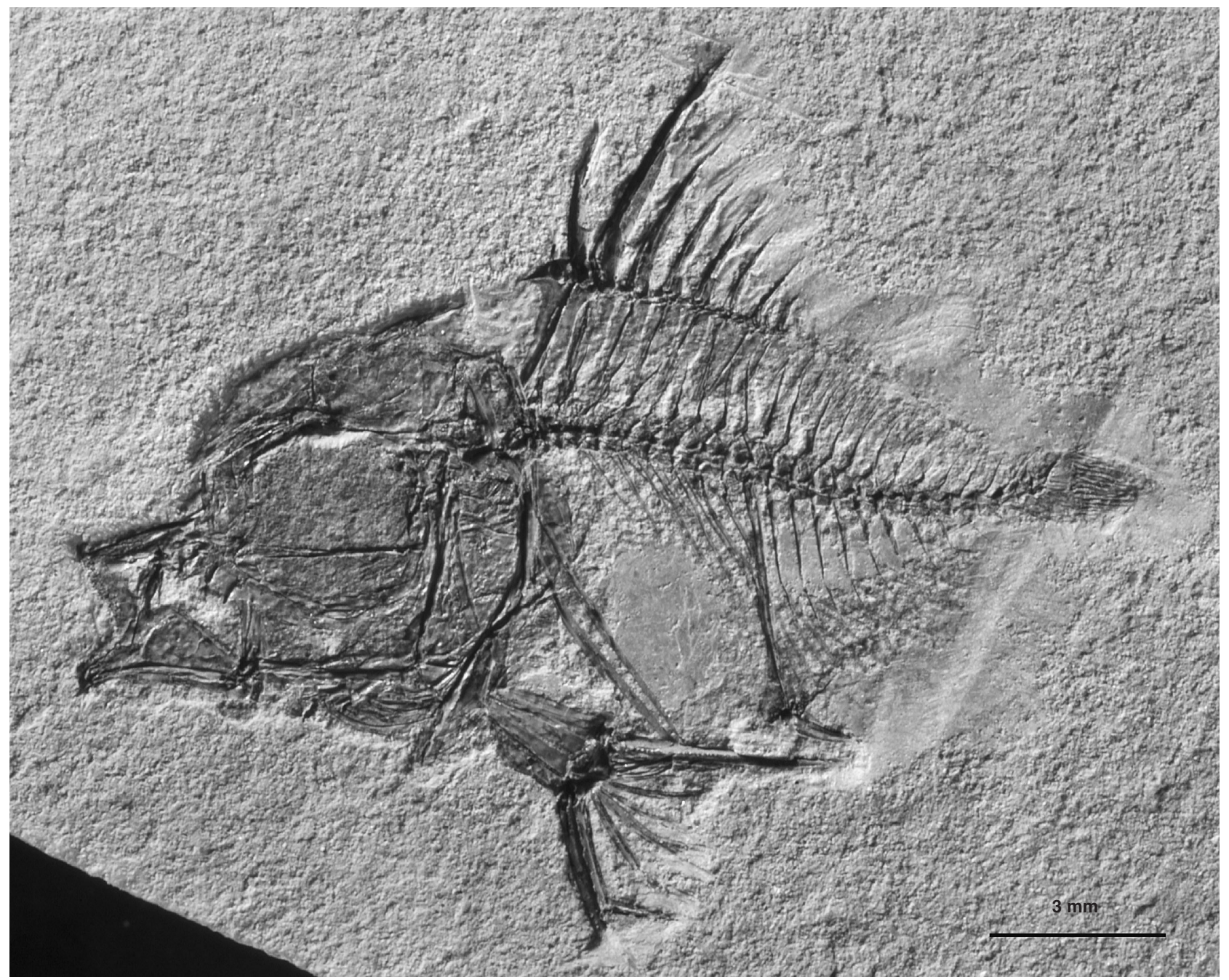

Figure 3. Caprosimilis carpathicus gen. et sp. nov., holotype, right part, MWGUW ZI/57/013/a.

end of the alveolar process is probably simple [14-0], it does not form a pair of lobes nor is it deeply bifurcated ventrally. The base of the articular process of the left premaxilla is invisible (in this region only the right maxilla is visible). If the mouth were closed, the ascending processes would probably reach no more than $1 / 5$ into the orbit [15-0]. The size of the mouth is large, the alveolar process is a little longer than the depth of the lateral ethmoid [12-0].

The lower jaws are triangular, exposed as the medial and lateral faces of the right lower jaw and the ventral edge of the left lower jaw. The dentary has a few small, pointed teeth; its dorsal edge is sinusoidal. The dentary probably makes up less than one half of the lower jaw, but the boundary of it and the dermarticular (angulo-articular) at the ventral edge cannot be determined. On the ventral edge and near the dentary symphysis are two small spines [22-2]. The anterior spine is visible on the right part on the right dentary; the posterior spine is visible on the left part on the left dentary.

The dermarticular is triangular, probably a little lower than the dentary and forming a little more than one half of the jaw. The retroarticular process is prominent and deep, with a posterior spike situated at the posteroventral corner. Its boundary with the dermarticular is probably indicated by a deep fissure between the bones (visible on the right part) showing as a rather large retroarticular.

As preserved, the upper and lower jaws are fully protruded, with the ascending processes of the premaxillaries extended in front of the ethmoid region. They may may have had asliding articulation along rostal cartilages on top of the low ethmo-vomer complex (barely visible). The lower jaw as preserved is horizontal, but if closed the mouth would have swung upwards nearly 45 degrees.

Most of the hyoid arch is preserved, but none of the branchial arches are exposed. The hyomandibula on the right part seems to have a slightly divided head articulating under the pterotic edge. It has a strong lateral ridge along the preopercle. There is a weak indication of a short ventro-rostrally directed process at the posterior edge of 


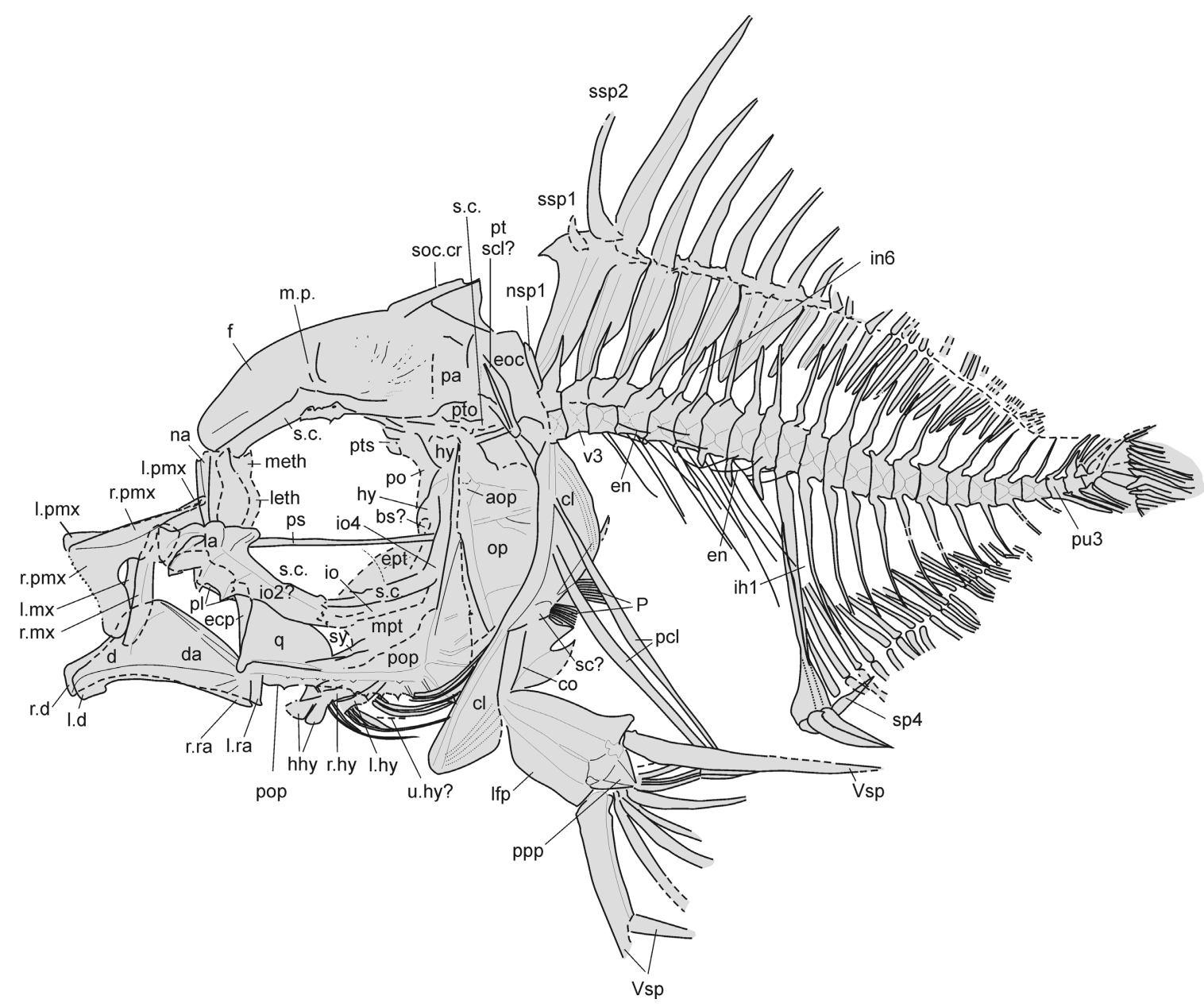

Figure 4. Caprosimilis carpathicus gen. et sp. nov., holotype, right part, MWGUW ZI/57/013/a, camera lucida drawing with explanations/interpretations (for anatomical abbreviations see Materials and methods).

the orbit (not reaching the palate). We cannot determine where the hyomandibula meets the metapterygoid. The symplectic is long, strong, and slightly bent along the flange of the preopercle, and a ventral flange is absent [20-0]. Part of the tongue is exposed below the preopercle on both parts (Fig. 8), and the left side is shifted a slightly more ventrally than is the right side. A small part of the triangular posterior ceratohyal (called "epihyal" by Tyler et al. 2003 and Tyler \& Santini 2005) is seen above the posterior branchiostegals (on left part). The anterior ceratohyals appear to articulate with two hypohyal elements anteriorly, both with a sharp "corner" or process in front. The articulation between the two ceratohyals does not appear to have any indications of prominent bony interdigitating struts [36-0], and the two bones may be of equal depth [37-0?]. The ceratohyals seem to be rather slim and a little narrower in their middle regions, and without foramina or grooves indicated [33-3]. The ventral edge of the anterior ceratohyal is smooth [35-1]. The branchiostegal rays are placed along the ventral side of both ceratohyals [34-0], and there appear to be eight in two groups [103-0; visible on both parts], apparently $3+5$ as preserved on the left ceratohyals. The two anteriormost branchiostegals seen on both plates (Fig. 8) are from the anterior, right ceratohyal. Some branchiostegals are represented only by their heads, some are covered by the neighbours, but there is no possibility that there is less than seven. A straight line structure in between the two groups of branchiostegals does not look like a branchiostegal ray and could be the ventral edge of the urohyal. The brown colour of the shale near the brachiostegals and the probable ventral edge of the urohyal allow us to suppose that the urohyal is large [38-1?]. This, however, could be a trace of a straight interopercle (see Zehren 1987, fig. 7).

The opercle is high and narrow $($ ca $3.5 \times 1.5 \mathrm{~mm})$, with a vertical anterior edge; probably the dorsal part of the posterior edge of the opercle is parallel to this and without any traces of spines (no spines seem to disturb the imprint of the cleithrum). There are irregular, almost horizontal lines marking the upper part of the opercle (visible on the left 


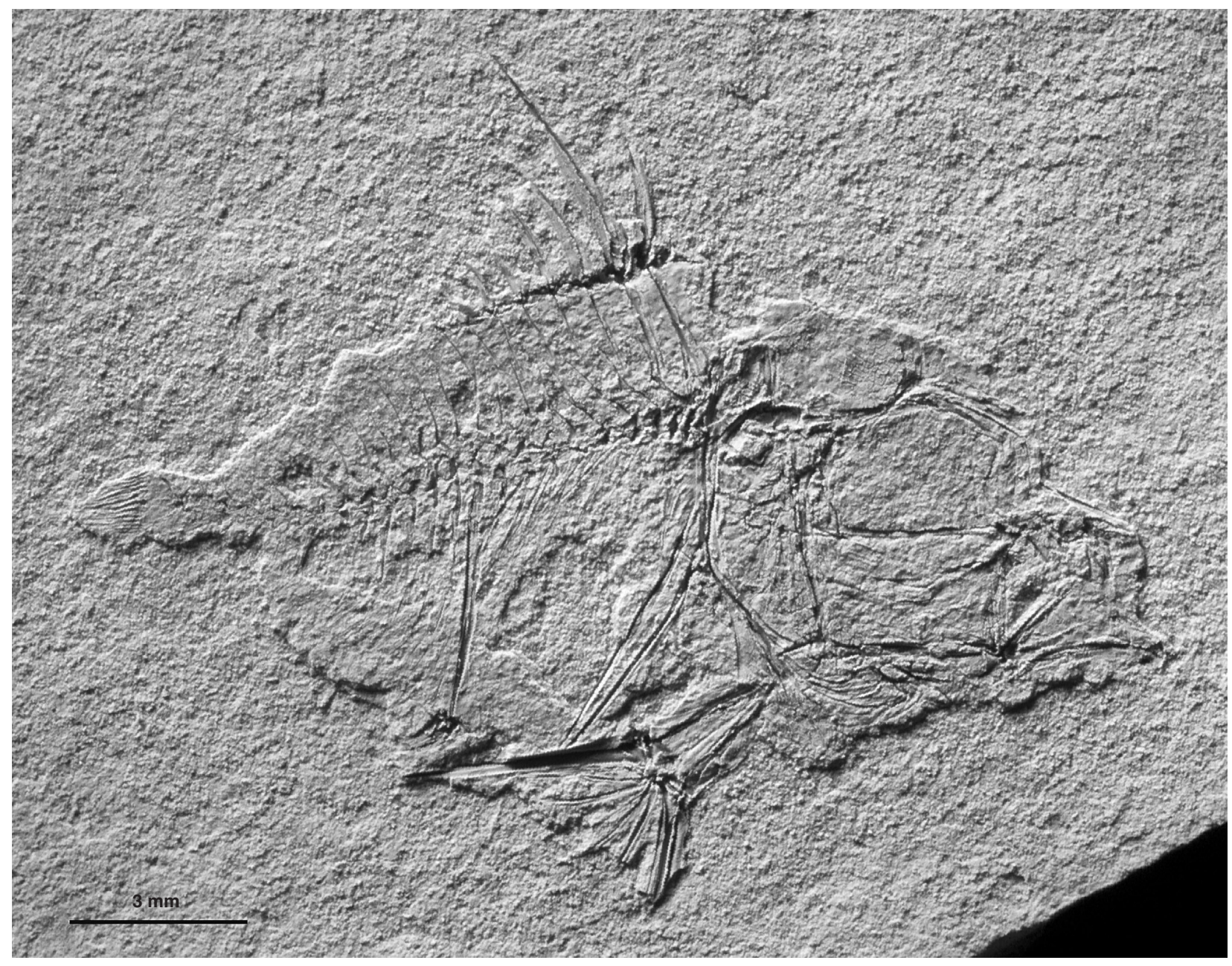

Figure 5. Caprosimilis carpathicus gen. et sp. nov., holotype, left part, MWGUW ZI/57/013/b, ammonium dusted.

part) which could be ridges that might end in small spines (which were not preserved because of the imprint by the cleithrum). Most of these linear markings on the upper part of the opercle are difficult to explain, but perhaps some could have been made by dorsal parts of the otherwise invisible branchial arches. The articularion of the opercle with the hyomandibula is situated slightly above the midline of the orbit.

Part of the subopercle is visible near the opercle, but the interopercle, that should be near the ventral edge of the opercle, is unvisible. On the right part there is a short distance between the anterior edge of the opercle and the posterior edge of the preopercle.

The vertical and horizontal brances of the preopercle (well preserved on both parts) meet at about a 90 degree angle, with the two branches of almost equal length, nearly $4 \mathrm{~mm}$. The strong imprints of the anterior and dorsal edges delimit the tube or the overhang for the sensory canals, and that of the ventral branch has at least ten small spines on its ventral edge, but the position of pores cannot be deter- mined. Both branches are rather slim, and at the angle between them there is a broad flange boardering the symplectic and metapterygoid. The vertical branch has short, well-separated posterior spines, with four along the lower half. Two distinct spines are at the angle between branches at the postero-ventral side. Short spines are evident along the ventral edge of the horizontal branch; there are probably more than five such spines. All of these spines are supported by low ridges on the bones.

Vertebral column. - There are 24 vertebrae [93-0]: 10 abdominal [94-1] and 14 caudal, including the terminal pu1+u complex. The two to three anterior centra are shorter antero-posteriorly than the following abdominal centra. The first vertebra seems to have its neural arch and spine firmly attached to the occipitals [40-1], and there is no free portion of the neural spine separated from the skull [42-0]. The neural spines of the second to sixth vertebrae are inclined backwards; the spine of the seventh vertebra is nearly vertical; the spine of the eighth vertebra is vertical; and 


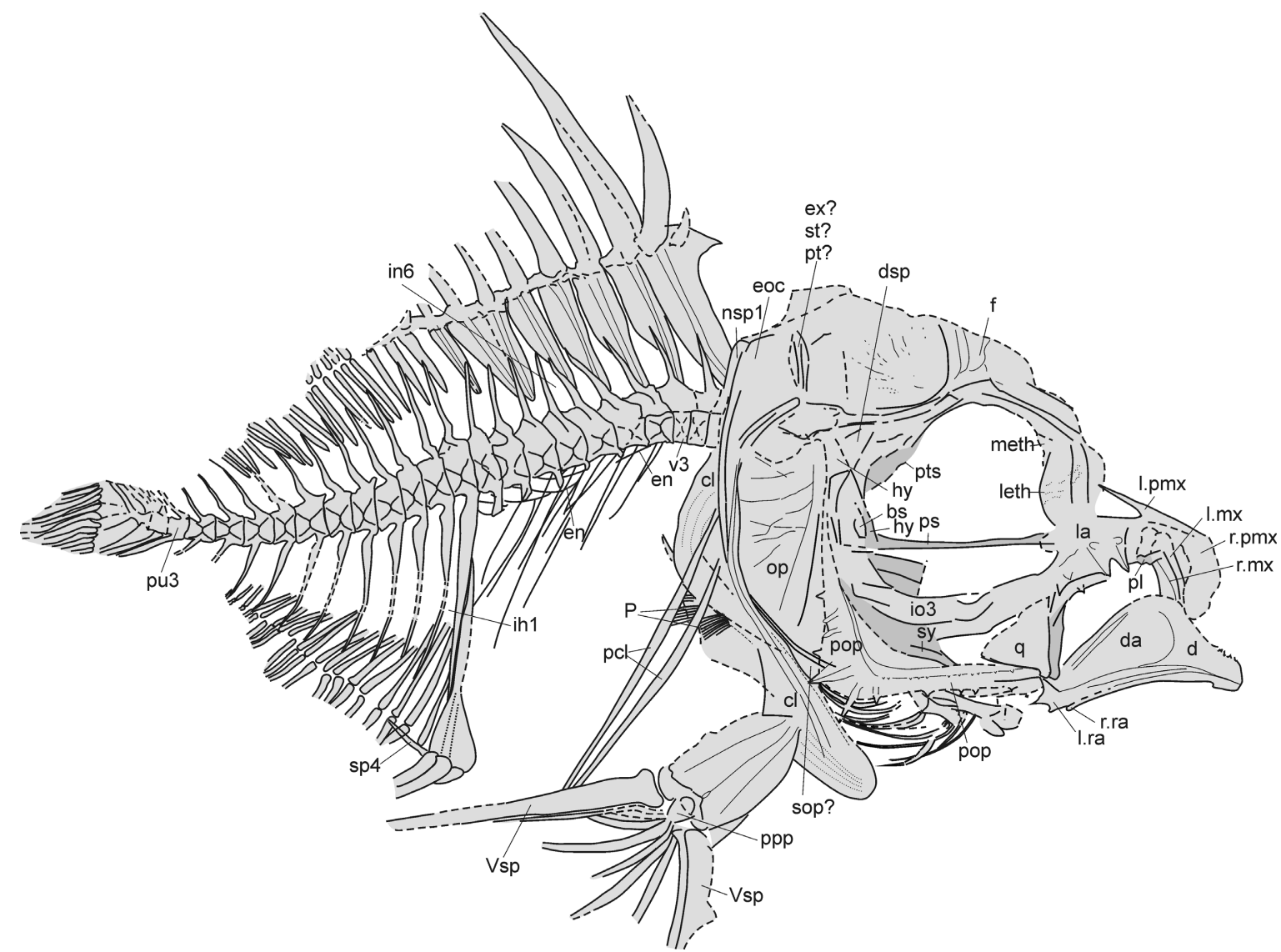

Figure 6. Caprosimilis carpathicus gen. et sp. nov., holotype, left part, MWGUW ZI/57/013/b, camera lucida drawing with interpretation (for anatomical abbreviations see Materials and methods).

those of the ninth and tenth are inclined slightly forward [44-1]. The ribs are slim and rather short and are present on the $4^{\text {th }}$ to $10^{\text {th }}$ vertebrae [ this meets the definition of $47-0$, but we prefer to give it the new state 47-6, ossified ribs on all of the abdominal vertebra except for the first three], the posterior ribs are short and very slim, measuring nearly half of the depth of the abdominal cavity. The three posteriormost ribs (on the $8^{\text {th }}$ to $10^{\text {th }}$ vertebrae) are attached to prominent parapophyses, and there seem to be small parapophyses on the $6^{\text {th }}$ and $7^{\text {th }}$ vertebra. All parapophyses are situated at the anterior edge of their centra. The posteriormost two parapophyses, which are the largest, are closed medially to form a haemal arch with a strong median spine [46-0]. The bases of the ribs on the $7^{\text {th }}$ and $8^{\text {th }}$ vertebra are so strong that it is difficult to determine if these have similar spines. All the neural arches appear to be high and attached to their neighbours by strong zygapophyses. The caudal peduncle probably contains four vertebra [95-1?], but the posterior rays of the dorsal and anal fin are poorly preserved.

Each of the ten anterior dorsal proximal radials (pterygiophores) of the dorsal fin are oriented into an abdominal interneural space, except for one [99-1]. The $6^{\text {th }}$ interneural space is vacant [58-inapplicable]. The first radial is situ- ated between the paired halves of the neural spines of the $1^{\text {st }}$ and $2^{\text {nd }}$ abdominal vertebrae. The remaining neural spines show no signs of being divided into two halfs. The $12^{\text {th }}$ and $16^{\text {th }}$ interneural spaces contain three radials, the $13^{\text {th }}-15^{\text {th }}$ and $17^{\text {th }}-18^{\text {th }}$ interneural spaces contain two radials.

The epineurals (formerly "epipleurals"; see Patterson \& Johnson 1995) are thin, horizontally situated on all of the ribs [48-0], and absent on the first three vertebrae. The centra in the transitional zone between the abdominal and caudal region are the largest, and tend to be slightly higher than long. The more posterior caudal vertebrae are slightly longer than high. All of the caudal vertebrae have slim neural arches and spines, and small articulation zygapophyses at the level of the end of the centra. The two anterior neural spines are nearly vertical, and the second and third are slightly diverging, with the second interneural space being the first with three radials (we count radials in interhaemal and interneural spaces when the proximal end is in this space). The remaining neural and haemal spines are inclined backwards. The first haemal spine is very strong, straight, nearly vertical,and has the first proximal radial (pterygiophore) of the anal fin along its anterior edge. In the prehaemal space there is one radial [69-2]. The first interhaemal space contains three radials [70-3], the second 


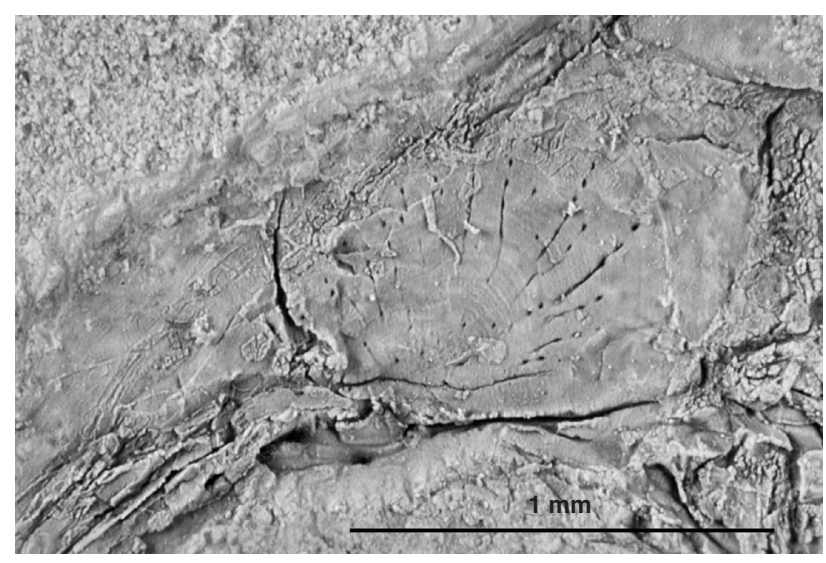

Figure 7. Caprosimilis carpathicus gen. et sp. nov. Caprozeus carpaticus gen. et sp. nov., holotype, right part, MWGUW ZI/57/013/a. Detail of skull roof showing ornamentation, ammonium dusted.

contains two radials [71-1;], with the number of radials in front of the haemal spine of third caudal vertebra being six [72-3]. The $4^{\text {th }}, 6^{\text {th }}$, and $8^{\text {th }}$ interhaemal spaces contain two radials; the $5^{\text {th }}$ and $7^{\text {th }}$ spaces contain three radials.

Caudal fin support. - The anterior support for the caudal fin (Fig. 9) is provided by the third preural centrum $\left(22^{\text {th }}\right.$ vertebra), which has long neural and haemal arches [39-1]. The neural spine of the second preural vertebra is short [49-1]. The neural and haemal arches of the third preural centrum (and those further anterior) are fused to their centra, while this is less certain for the haemal spine of second preural vertebra. The parhypural is strong, with a hypurapophysis [50-0], and it embraces the urostylar (first preural +ural) centrum [52-0]. There are three large epurals [51-0], best seen on the right part. Hypurals 1-3 are free and separate from the urostylar centrum. There is a separate plate of hypural 4 and the more dorsal hypurals are not fused to the urostylar centrum (degree of fusion of hypurals does not correspond to any state of character 53).

There are two uroneurals (the second is very thin) [54-0]. The extended anterior end of the first uroneural is stegural-like [55-0]. Posterior to the neural spine of the second preural vertebra and in front of the anterior margin of the first uroneural is a strong, triangular structure that ascends antero-dorsally (visible on both parts). It is probably a large zygapophysis like in Capros, and to some degree also in Antigonia (Rosen 1984) There is no extra ossicle of the haemal spine of the second preural centrum [56-0].

Median fins. - The caudal fin is not particularly well preserved; its rays are pressed together and their distal parts where branching would be present are missing. The procurrent rays are slightly misplaced and a few could be missing. Ventrally there is one small procurrent ray turned downwards. We assume that the ray just dorsal to this, of which only the strong base is preserved, is the large ventralmost principal ray. There are seven more rays in the ventral lobe up to the region between hypurals 2 and 3 . There are two small dorsal procurrent rays. We consider the ray just ventral to these as the dorsalmost unbranched pricipal ray, and thus there are eight dorsal principal rays. Therefore, there are 16 principal rays, without any of the branching parts preserved [96-0; could perhaps be 15 principal rays, 96-1], and three procurrent rays [97-3; perhaps 4 rays, 97-4].

The dorsal fin has nine spines [98-5] and 21 soft rays. The third spine is the longest, supported by the large first radial, and in front of the third spine there are two much smaller supernumerary spines [107-0]; the anteriormost spine is tiny. There is some indication of a median "handle-shaped" structure on the radial with a hole below it, and completely surrounded by the broad basis of the tiny first spine. This might be a "ring-link" articulation like in caproids, where the bases of the anterior spines have anterio-posterior tubular cavities through which such "handles" course. The type of articulation is more difficult to determine at the subsequent larger spines because their bases are so broad and close together. The proximal postero-lateral spikes on the three anterior spines probably indicate a locking mechanism between these three spines [57-3]. The first dorsal proximal radial (pterygiophore) has a distal forward pointing spike; the radial slants backwards and is situated in the first interneural space [60-1] where it contacts the skull [61-1]. There are three radials in front of the neural spine of the fourth abdominal vertebra [59-2]. The distal radials are very difficult to see; there is only a little space for them, so presumably they were at least reduced [62-1?] in size.

There are 21 soft dorsal rays, preserved only proximally, and it is impossible to determine if they were branched [73-?]. The soft dorsal-fin base ends above the level of the middle of the $4^{\text {th }}$ preural centrum, just in front of the $5^{\text {th }}$ neural preural spine and slightly behind the anal-fin base. There is no predorsal (supraneural) in front of the dorsal fin [64-0].

All of the proximal radials (pterygiophores) of the spines and of the 2-3 anteriormost soft rays have large anterior and posterior flanges making them more or less symmetrical and rather broad, though decreasing in size posteriorly in the series. The radials of the majority of the soft rays are slim rods without flanges, and we presume that they are symmetrical [63-0]. The same applies for the radials of the soft anal fin. The lack of flanges could be a juvenile feature.

The anal fin has four spines [100-4]; the first is tiny, the second is the largest [68-0 is the best coding match, but this is relatively meaningless when there is a tiny $1^{\text {st }}$ spine, so therefore we do not utilize coding for this condition]. The third spine is slightly smaller, and the fourth spine is slim. 

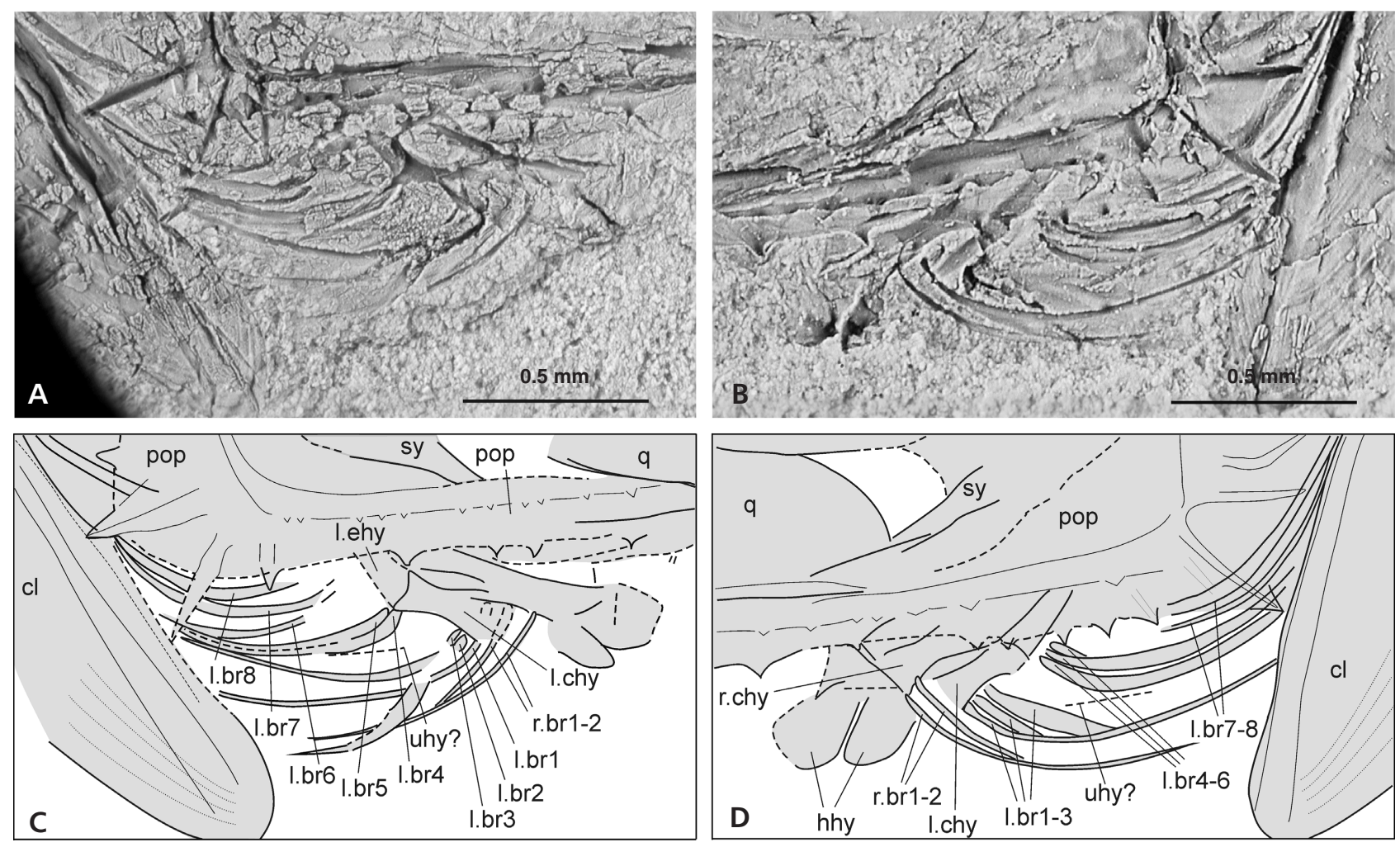

Figure 8. Caprosimilis carpathicus gen. et sp. nov., holotype. Branchiostegals and preopercle with spine pattern. - A - right part, MWGUW ZI/57/013/a, ammonium dusted. • B - left part, MWGUW ZI/57/013/b, ammonium dusted. • C - right part, camera lucida drawing. • D - left part, camera lucida drawing. For anatomical abbreviations see Materials and methods.
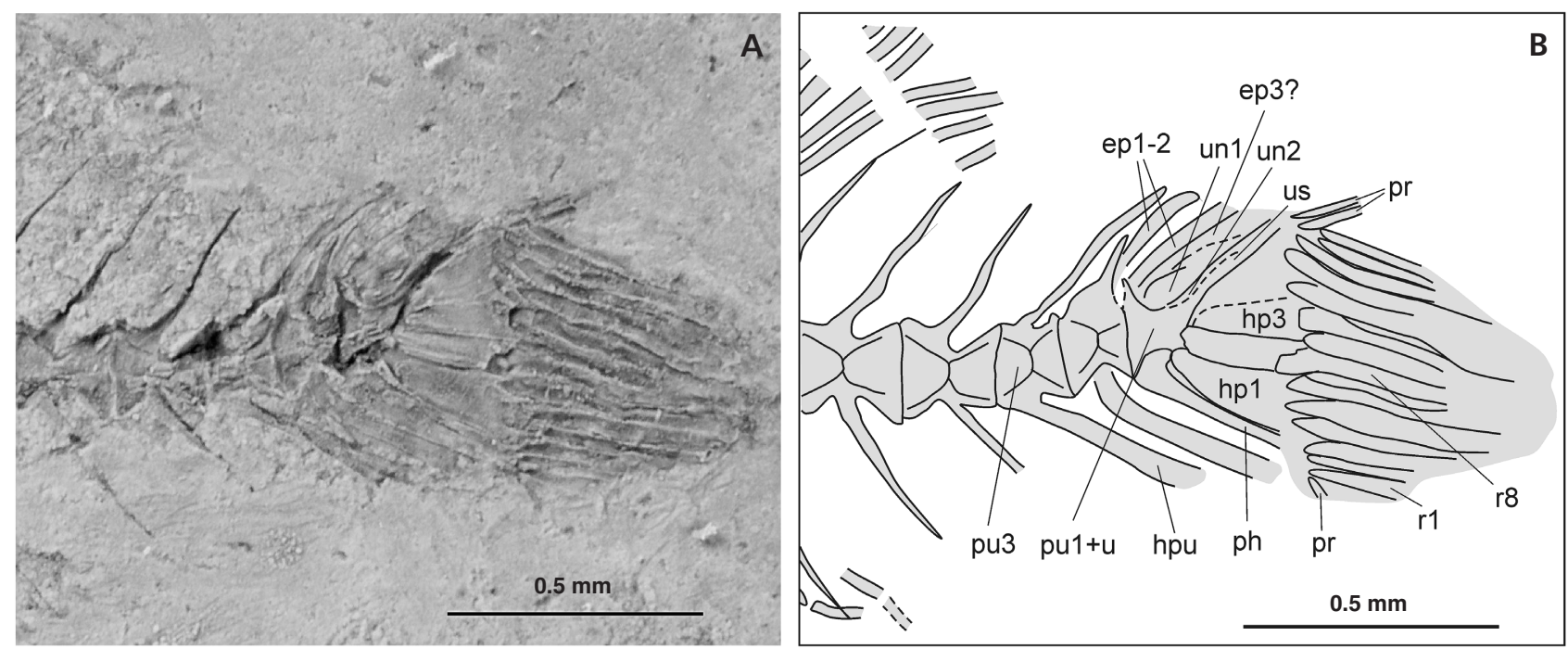

Figure 9. Caprosimilis carpathicus gen. et sp. nov., holotype, right part, MWGUW ZI/57/013/a. Caudal region and fin. • A - ammonium dusted, $\mathrm{B}$ - camera lucida drawing (for anatomical abbreviations see Materials and methods).

The fourth spine is as preserved near to the ventral margin of body, displaced from its radial. The homologies between the anal spines could possibly be that the A II-IV of $C$. carpathicus gen. et sp. nov. is homologous with the A I-III of zeiforms and caproids. Caprosimilis carpathicus gen. et sp. nov. has three supernumerary anal spines on the first radial. A locking mechanism may be present between the first and second spine [66-1], and possibly also present between the second and third spines. The best indication of a locking mechanism is the strong proximal dorso-lateral spike on 
the second spine. There is no fusion between the first small spine and the large radial [67-0], although the articulation seems very close. The $1^{\text {st }}$ proximal radial (pterygiophore) is long, strong, and expanded near its ventral margin, and it covers most of the front edge of the haemal spine. The anal fin has 18 soft rays, which are preserved only proximally and thus it is not possible to determine if they are branched [73-?]. The anal fin as preserved terminates below the level of the middle of the $5^{\text {th }}$ preural vertebra, just behind the haemal spine of the $6^{\text {th }}$ preural vertebra. There may be a dissociated short ray or radial situated just behind the haemal spine of the $6^{\text {th }}$ preural vertebra and below the middle of the $4^{\text {th }}$ preural vertebra, so 1-2 rays may be displaced, and the true number could be about 20 rays.

Pectoral girdles and fins. - The pectoral fins are almost invisible, with only a few thin rays indicated between and crossing near the proximal ends of the postcleithra. The cleithrum is large, sinusoid, and bending, with a broad lateral flange ventrally and a large, rounded posterior flange dorsally, with evident growth-lines. There is no posterior process on the cleithrum above the articulation with the postcleithrum [79-0]. It is difficult to determine where the bone ends above the flange, but there seems to be about one $\mathrm{mm}$ of a slim process. On right side, the upper part of the cleithrum meets a slim lancet-shaped and nearly vertical bone with a tube running its entire length. This is in position as a supracleithrum.

The postcleithrum is single [75-1], long, and slim, with no trace of a flat, separate, dorsal element, and with no flanges [76-0]. It reaches the ventral margin of the body between the anal fin origin and the pelvic fin base.

The coracoid (visible on both parts) shape is unclear, although the postero-dorsal process is visible. Above this the area below the postcleithrum is the scapula, possibly with a foramen weakly indicated at the border to the coracoid (on the right part). No radials can be distinguished.

Pelvic girdle and fins. - The position of the pelvic-fin base is below and slightly behind the pectoral-fin base [81-2]. The pelvic fin has a large, strong spine [82-0] reaching beyond the anal fin spines, and five soft rays (visible in left and right fin), so it has six elements [102-3] of which the distal ends are not preserved (the right fin has a broken spine). Two of the rays are spread out and turned, and thus expose the broad flanges near their bases [83-2], none of which seem to have any serrations [84-0].

The pelvis is visible from both its ventral and dorsal sides because it is turned 90 degrees. Excluding the postpelvic process, it is $c a 2 \mathrm{~mm}$ long, and it only overlaps the cleithrum slightly. The two postpelvic processes are preserved (visible on the right part as a deep imprint) with their bases close to the midline. The postpelvic processes are rather broad and probably short to moderately long
[86-0?]. The pelvis is very wide, about $1.3 \mathrm{~mm}$ at the posterior margin, but it is most likely that the two rather broad lateral flanges were turned much more downward, perhaps nearly vertical, as in Capros. Deep fissures of the dorsal and lateral flanges of the pelvis are evident.

The two halves of the pelvis seem partially fused along most of the midline [85-3], with just a small open slit at the posterior end, where there are indistinct traces of small posterior medial processes, but little overlapping [85-1, so we code it as $85-1+3]$. The pelvis is oriented at an angle about of 45 degrees.

Scales. - The scales can be observed in the pre-anal field of the ventral region of the body, and they probably covered all of the body but not the head. In the postero-dorsal region of the body there seems to be a light brown coloration between the radials, indicating some squamation; the pattern in both areas, though not very clear, seems to show small roundish scales. The scales are scarcely overlapping and are about $1 / 5 \mathrm{~mm}$ in diameter. There seems to be a thin spike in the middle of each scale, and such tiny spines are seen all over the body. There are neither buckler-like scales [88-0] nor scute-like scales [89-0], nor modified scales along bases of the anal and dorsal fins [90-1?]. At least the latter, but perhaps all, of these scale characters could be due to a juvenile condition and very small size, at which the specimen might not have yet developed such dermal structures.

There is no sign of hyperosteosis in any bones or scales [91-0], but none could be expected at this size of specimen. There is no sign of extended prejuvenile stage with late ossification and cone-like scales.

Remarks. - The specimen is very small (less than $17 \mathrm{~mm}$ SL), but well ossified. Probably it was an individual at an early adult stage. The same is true of the only known specimens of Archaeozeus and Protozeus, which do, however, in the shape of their braincases show clear sign of being juveniles.

Tyler \& Santini (2005) noted that all the earliest and most primitive forms of caproids, tetraodontiforms, and zeiforms are individuals of less than $6 \mathrm{~cm} \mathrm{SL}$, and all are much smaller than their extant relatives. Tyler et al. (2003) and Tyler \& Santini (2005) suggested that paedomorphic processes were important in the early evolution of all three groups. We suggest that a simpler hypothesis is that the last common ancestor of the zeomorphs was already a very small species.

\section{Phylogenetic analysis}

The phylogenic analysis of zeiforms by Tyler et al. (2003) used 103 morphological characters, and Tyler \& Santini 


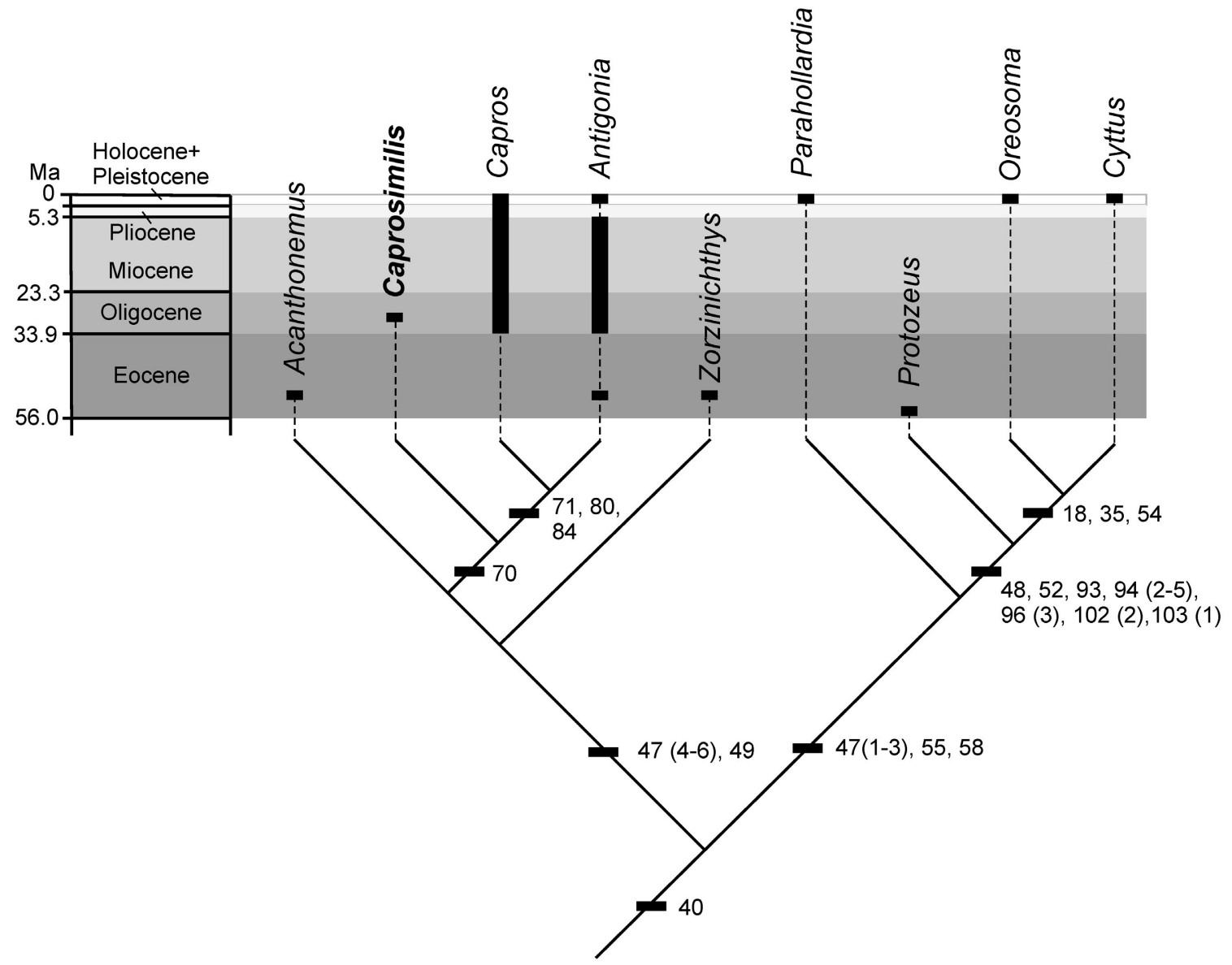

Figure 10. Phylogenetic scheme of the ten genera analysed manually with their fossil record.

(2005) used the same list and included fossil taxa, as well as adding four new characters. We found it possible to code C. carpathicus gen. et sp. nov. for 67 of the 107 character states utilized by Tyler \& Santini (2005), and we add one new character in our analysis.

We compared $C$. carpathicus gen. et sp. nov. to extant Capros aper and Antigonia capros (Caproidae); Parahollardia lineata (Tetraodontiformes); Cyttus novaezelandiae, C. australis, C. traverse, Oreosoma atlanticum (Zeiformes) and to three extinct genera: Protozeus kuehnei, Acanthonemus subaureus, Zorzinichthys annae. For those species we used the coding of character states from Tyler \& Santini (2005), except that we improved the coding of a few states of Protozeus and one state of Antigonia (see Appendix 2). We did not compare to Early Eocene Eoantigonia veronensis (see Sorbini 1983, Sorbini \& Bottura 1988, Baciu et al. 2005b) because it is the sister taxon to Antigonia (see Tyler \& Santini 2005) and we did not use the Oligocene Capros caprosoides, C. longispinatus, C. rhenanus (see Baciu et al. 2005b) and the Miocene $C$. arambourgi (see Baciu et al. 2005a) because they are sufficiently similar to the extant Capros aper to be accommodated in the same genus. We did not compare the new species to Archaeozeus because its anal fin region is missing and it lacks the pelvis, pelvic fin, and most of the soft dorsal fin. We have not included in the phylogenetic analysis Cretaceous Cretazeus rinaldii (Tyler et al. 2000) referred to zeiforms by Tyler \& Santini (2005), nor Plectocretacicus clarae (Sorbini 1979) and Cretatriacanthus guidottii (Tyler \& Sorbini 1996) related as primitive sistergroup to tetraodontiforms by Tyler \& Santini (2005), because many of their morphological characters are unknown; $P$. clarae is the earliest ( ca $95 \mathrm{Ma}$ ) representative of zeomorphs sensu lato. We did not compare to Microcapros libanicus from Cretaceous, because we do not believe it is a caproid as it was indicated by Zehren (1987, unpublished MS), Bannikov (1991), Patterson (1993) and Tyler et al. (2003).

We selected Naso unicornis (Perciformes, Acanthuridae) as the single outgroup with the full data set (Fig. 11, Appendix 2A, B), following the results of the phylogenetic analysis by Tyler \& Santini (2005).

We constructed a matrix of ten genera and 85 characters (Appendix 2). All characters were treated as unordered and unweighted. Characters states that could not be determined from the fossils because of inadequate preservation 


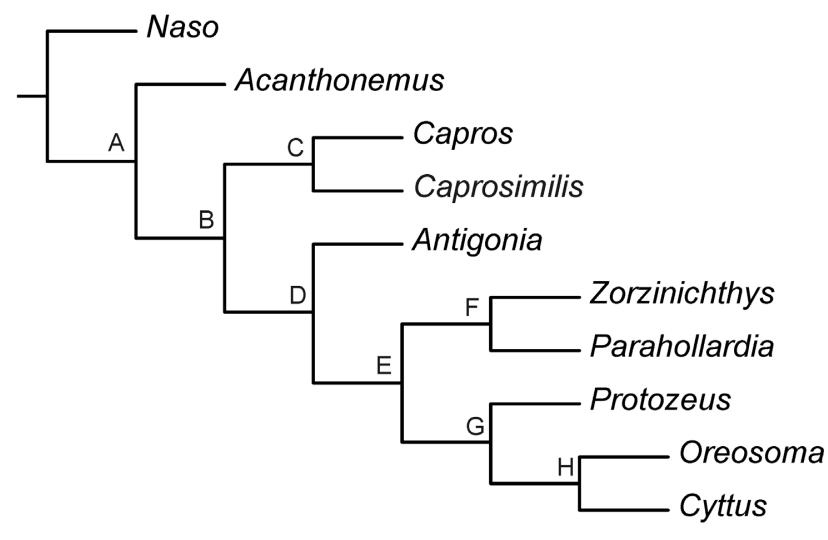

Figure 11. Estimated consensus tree of the ten genera.

are coded as unknown, and indicated in the data matrix by a question mark. We show some characters states (Appendix 2) that were determined with question mark (i.e. 1?), but in the phylogentic analysis they were treated as unknown. We analysed the matrix manually searching for synapomorphies that could characterize monophyletic groups and with TNT v. 1.1 (Goloboff et al. 2008), using the estimated consensus algorithm with simple addition sequence and TBR (tree bisection-reconnection) branch-swapping options.

The full list of anatomical features are given in Appendix 1, and the distribution of the stages among the taxa analysed are given in Appendix 2A, B.

\section{Results of the phylogenetic analysis}

Among the 85 characters analyzed manually, we selected those that uniquely characterize monophyletic groups on the phylogenetic model of the zeomorph clade proposed by Tyler \& Santini (2005). The topology of our phylogenetic model (Fig. 10) in general is similar to the majority consensus tree in Tyler \& Santini (2005). The only difference is that we did not find any synapomorphy for Zorzinichthys and Parahollardia, but we did find support for the clade formed by C. carpathicus gen. et sp. nov., Acanthonemus, caproids, and Zorzinichthys (Fig. 10). Caprosimilis carpathicus gen. et sp. nov., appears as the sister-group to caproids (Capros and Antigonia).

The monophyletic groups in the manually constructed tree can then be characterized as follows (see Fig. 10). Cyttus and Oreosoma have three synapomorphies: the palatine is usually orientated distinctly obliquely to the body axis and has a single, pivotal, articulation with the lateral ethmoid, resulting in considerable mobility [18]; the ceratohyal has prominent notches for the heads of some of the branchiostegal rays in the anterior group [35]; and uroneurals are absent [54]. Zeiformes (Protozeus, Cyttus, and Oreosoma) have seven synapomorphies: ossified epineurals present only on a few of the anterior abdominal vertebrae [48], parhypural articulation with the proximal end to the urostylar centrum is slightly removed from and not embracing the centrum [52]; total number of vertebrae 31 to 42 [93]; number of abdominal vertebrae 11 to 14 [94]; number of principal caudal-fin rays 13 [96]; total number of pelvic-fin elements 7 [102]; number of branchiostegal rays seven $-3+4$ [103]; Zeiformes plus tetraodontiformes (Protozeus, Cyttus, Oreosoma, and Parahollardia) have three synapomorphies: ossified ribs present only on the last few abdominal vertebrae or absent [47]; stegural (sensu Rosen 1984) absent [55]; number of groups of vacant interneural spaces (when two or more spaces are vacant) two to four [58]. Caproids (Antigonia and Capros) have three synapomorphies: number of anal-fin pterygiophores in the second interhaemal space (between the haemal spines of the second and third caudal vertebrae) three to four [71]; extrascapular are two tubular bones, not closely held to the skull, except at larger specimen sizes or three more or less tubular bones [80]; serrations of pelvic-fin rays are present on crests on the anterior or upper and/or the lower posterior surfaces of several rays [84]. C. carpathicus gen. et sp. nov. and caproids have one synapomorphy: number of anal-fin pterygiophores in the first interhaemal space (between the haemal spines of the first and second caudal vertebrae) is three to five [70]. C. carpathicus gen. et sp. nov., Acanthonemus, caproids, and Zorzinichthys have two synapomorphies: ossified ribs present on all of the abdominal vertebrae except the first, first two or first three [47]; length of the neural spine of second preural centrum - absent to short [49]. All analysed zeomorphs have one synapomorphy: first vertebra, association of the neural arch and spine with the skull - the neural arch and spine are closely applied to the skull, primarily to the exoccipitals or the neural arch and base of the spine are closely applied to the skull, but most of the spine is free from the skull [40].

The phylogenetic analysis using an estimated consensus algorithm produced a single tree (Fig. 11, Appendix 3), with a total length of 167 , a consistency index (CI) of 0.731 , and a retention index (RI) of 0.559 . The sister-group relationship between $C$. carpathicus gen. et sp. nov. and Capros is supported. The topology of the estimate consensus tree (Fig. 11) in general is similar to the majority consensus tree in Tyler \& Santini (2005). A suprising difference is that Antigonia does not form a clade with Capros but, rather, is the sister-group to Zorzinichthys, Parahollardia, and zeiforms. Osteological studies (Rosen 1984, Tyler et al. 2003, Tyler \& Santini 2005) and some molecular analyses recognized Capros and Antigonia as sister groups, while other molecular analyses placed them far from each other (Li et al. 2009, Near et al. 2013). A zeiform clade (Protozeus, Cyttus, Oreosoma) is supported by eight synapomorphies. The sister-group relation- 
ship between Zorzinichthys and Parahollardia is supported by five synapomorphies and the sister-group relationship between this group and zeiforms is supported by three synapomorphies. Synapomorphies for Zorzinichthys and Parahollardia are: (1) absence of supraocular serrations on frontal; (2) absence of postmaxillary process; (3) the neural spines of all (or all but the first few) of the abdominal vertebrae are orientated posterodorsally; (4) analfin pterygiophores, number anterior to the haemal spine of the third caudal vertebra is three; (5) postcleithrum, number of separate bony elements is two. The first, second, and fifth characters are present also in Acanthonemus, and the third is present in Capros.

The manually constructed tree corresponds well to the fossil record (Fig. 10). Acanthonemus and Zorzinichthys are known from Monte Bolca deposits that are dated as the Early Eocene, ca 50 Ma (Medizza 1975, Papazzoni \& Trevisani 2006). Capros is known from the Early Oligocene (ca 33.9 Ma) to Recent (Baciu et al. 2005b, Nolf \& Tyler 2006, Kotlarczyk et al. 2006). Antigonia is known from the late Early and Middle Eocene ( ca $50 \mathrm{Ma}$ ), Oligocene-Miocene ( ca 33.9-5.3 Ma) and Recent (Sorbini \& Bottura 1988, Radwańska 1992, Baciu et al. 2005b, Kotlarczyk et al. 2006, Nolf \& Tyler 2006). The so-called "Antigonia", the very first Danish "Danekræ" fossil (Bonde \& Christiansen 1991, Bonde et al. 2008), from Stolleklint Clay, the earliest Eocene, ca 55.7-55.5 Ma (see Gradstein et al. 2004, as it is equivalent to the Paleocene-Eocene Temperature Maximum, just underlying the mo-clay diatomite of Fur Formation, Lower Ypresian, in North Jutland, Denmark) may not be a close relative of Antigonia, due to some anatomical details despite its superficial resemblance.

Parahollardia, Oreosoma, and Cyttus are Recent taxa. Protozeus and another primitive zeiform, Archaeozeus skamolensis, are from Mo-clay (Fur Formation - see Bonde 1987, 1997; Bonde et al. 2008, 2011). The age of the Fur Fm. is the earliest Lower Eocene, about 55.5-54 Ma, and both species are from the lower half of the formation, about $55 \mathrm{Ma}$ as stated correctly by Tyler et al. (2000, p. 12), but incorrectly as 58-59 Ma by Tyler et al. (2003), Tyler \& Santini (2005) and Baciu et al. (2005c).

In the tree produced by the estimated consensus algoritm, the relationship of zeiforms, Zorzinichthys, and Parahollardia is the same as in majority rule consensus tree presented by Tyler \& Santini (2005).

The most important result of our analysis is that C. carpathicus gen. et sp. nov. appears to form a clade with Capros or to form a sister-group relationship with the clade formed by Capros and Antigonia.

Secondly, our analysis indicates that two synapomorphies can support a clade formed by $C$. carpathicus gen. et sp. nov., Acanthonemus, caproids, and Zorzinichthys.

\section{Comparison}

Caprosimilis carpathicus gen. et sp. nov. differs from extant (Capros aper and Antigonia capros) and extinct (Lower Eocene Eoantigonia veronensis, Lower Oligocene Capros caprosoides, C. rhenanus, Proantigonia cosmovici, Upper Oligocene Capros longispinatus and Upper Miocene Capros arambourgi, Proantigonia dagestanica, P. octacantha, P. radobojana) Caproidae (see Tyler et al. 2003; Baciu et al. 2005a, b; Tyler \& Santini 2005). Differences are as follows (contrasting characters are given in parentheses): number of vertebrae 24 (versus 21-23), and number of branchiostegal rays eight (versus six), number of anal-fin spines four (versus three), number of principal caudal-fin rays 16 (versus 12 or 14). It differs also from Proantigonia by having two supernumerary dorsal-fin spines (versus one), no spinules on soft dorsal- and anal rays (versus soft dorsal- and anal spines bear spinules). Caprosimilis carpathicus gen. et sp. nov. differs from Antigonia additionally as follows: ceratohyal without foramen, angle between anterodorsal margin of supraoccipital and top of rear brain case less than 90 degrees. It differs also from $E o$ antiginia by absence of a single, large, strong tooth directed anteriorly and curved in premaxilla and dentary; basal region of shaft of first dorsal-fin pterygiophore between first and second neural spines, angle between anterodorsal margin of supraoccipital and top of rear brain case less than 90 degrees. It has the anterior angle of the supraoccipital crest on the vertical line through the posterior edge of the orbit like C. arambourgi, C. caprosoides, C. rhenanus, C. longispinatus, and P. cosmovici. Caprosimilis carpathicus gen. et sp. nov. has three measurements similar to Capros arambourgi (head length in standard length, maximum body depth in standard length, head length of body depth). Although it resembles extinct caproids such as Proantigonia cosmovici, Capros caprosoides and $C$. rhenanus in body proportions it differs from them, however, in measurements (see Table 1). It shares head length in standard length with Proantigonia cosmovici, maximum body depth in standard length with Proantigonia radobojana and $C$. rhenanus, head length in body depth with $P$. radobojana.

The mouth region of Caprosimilis carpathicus gen. et sp. nov. is very similar to that of Capros (Zehren, unpublished MS) and most caproids (Baciu et al. 2005b), but with a broader (more primitive) distal maxilla like that in Antigonia and most zeiforms (Zehren 1987, Świdnicki 1988, Tyler et al. 2003). It also has a premaxilla with proportions that are not extremely high and narrow, like that in Capros. The morphology of the first uroneural of C. carpathicus gen. et sp. nov. is stegural-like, similar to that of the Recent Capros aper, but $C$. aper has variation of this (see Tyler et al. 2003; coding [55-0/1]).

The large zygapophysis on the preural-ural vertebra of Caprosimilis carpathicus gen. et sp. nov. resembles the 
Table 1. Comparison of osteology and measurements of Caprosimilis carpathicus gen. et sp. nov. and Oligocene-Miocene caproids.

\begin{tabular}{|c|c|c|c|c|c|c|c|c|c|c|}
\hline & $\begin{array}{l}\text { Numer of } \\
\text { vertebrae } \\
\text { (number of } \\
\text { abdominal } \\
\text { + caudal } \\
\text { vertebrae) }\end{array}$ & Anal fin & Dorsal fin & $\begin{array}{l}\text { Position of the } \\
\text { anterior angle of the } \\
\text { supraoccipital crest } \\
\text { in relation to the } \\
\text { vertical line through } \\
\text { the posterior edge of } \\
\text { the orbit }\end{array}$ & $\begin{array}{c}\text { Vacant } \\
\text { inter-neural } \\
\text { space }\end{array}$ & $\begin{array}{l}\text { Head } \\
\text { length in } \\
\text { standard } \\
\text { length }\end{array}$ & $\begin{array}{c}\text { Maximum } \\
\text { body depth } \\
\text { in standard } \\
\text { length }\end{array}$ & $\begin{array}{l}\text { Head } \\
\text { length } \\
\text { of body } \\
\text { depth }\end{array}$ & $\begin{array}{c}\text { Horizontal } \\
\text { diameter } \\
\text { of orbit } \\
\text { of standard } \\
\text { length [in \%] }\end{array}$ & Age \\
\hline $\begin{array}{l}\text { Caprosimilis } \\
\text { carpathicus gen. } \\
\text { et sp. nov. }\end{array}$ & $\begin{array}{c}24 \\
(10+14)\end{array}$ & IV, 20 & IX, 21 & On the line & $6^{\text {th }}$ & 2.55 & 1.8 & 0.72 & 18 & $\begin{array}{l}\text { Lower } \\
\text { Oligocene }\end{array}$ \\
\hline $\begin{array}{l}\text { Capros } \\
\text { arambourgi }\end{array}$ & $\begin{array}{c}22 \\
(10+12)\end{array}$ & III, 19-20 & IX, 20-21 & $\begin{array}{l}\text { On the line } \\
\text { or slightly anterior }\end{array}$ & $6^{\text {th }}$ & $2.2-2.6$ & $1.8-2.0$ & $0.6-0.8$ & - & $\begin{array}{l}\text { Upper } \\
\text { Miocene }\end{array}$ \\
\hline $\begin{array}{l}\text { Capros } \\
\text { caprosoides }\end{array}$ & $\begin{array}{c}22 \\
(10+12)\end{array}$ & III, 18-19 & IX, 18-19 & $\begin{array}{l}\text { On the line } \\
\text { or slightly anterior }\end{array}$ & $6^{\text {th }}$ or $7^{\text {th }}$ & $2.1-2.3$ & $2.2-2.8$ & $1.0-1.3$ & - & $\begin{array}{l}\text { Lower } \\
\text { Oligocene }\end{array}$ \\
\hline $\begin{array}{l}\text { Capros } \\
\text { rhenanus }\end{array}$ & $\begin{array}{c}23 \\
(10+13)\end{array}$ & III, 20-22 & IX, 21-22 & $\begin{array}{l}\text { On the line } \\
\text { or slightly posterior }\end{array}$ & $6^{\text {th }}$ or $7^{\text {th }}$ & $2.2-2.4$ & $1.8-2.2$ & $0.8-1.0$ & - & $\begin{array}{l}\text { Lower } \\
\text { Oligocene }\end{array}$ \\
\hline $\begin{array}{l}\text { Capros } \\
\text { longispinatus }\end{array}$ & $\begin{array}{c}22 \\
(10+12)\end{array}$ & III, 20 & IX, 25 & $\begin{array}{l}\text { On the line } \\
\text { or slightly anterior }\end{array}$ & $5^{\text {th }}$ or $6^{\text {th }}$ & $2.3-2.5$ & $1.5-1.6$ & 0.65 & 15 & $\begin{array}{l}\text { Upper } \\
\text { Oligocene }\end{array}$ \\
\hline $\begin{array}{l}\text { Proantigonia } \\
\text { cosmovici }\end{array}$ & $\begin{array}{c}23 \\
(10+13)\end{array}$ & III, 20-21 & VIII, 20 & On the line & $7^{\text {th }}$ & $2.4-2.55$ & $2.0-2.2$ & $0.82-0.89$ & $15-16$ & $\begin{array}{l}\text { Lower } \\
\text { Oligocene }\end{array}$ \\
\hline $\begin{array}{l}\text { Proantigonia } \\
\text { dagestanica }\end{array}$ & $\begin{array}{c}23 \\
(10+13)\end{array}$ & III, 20 & VIII, 19 & Anterior & $6^{\text {th }}$ and $9^{\text {th }}$ & 2.6 & 2.3 & 0.88 & 12 & $\begin{array}{l}\text { Upper } \\
\text { Miocene }\end{array}$ \\
\hline $\begin{array}{l}\text { Proantigonia } \\
\text { octacantha }\end{array}$ & $\begin{array}{c}21 \\
(10+11)\end{array}$ & III, 16-17 & VIII, 16,17 & Anterior & $6^{\text {th }}$ & $2.0-2.2$ & $2.0-2.4$ & $1.0-1.1$ & - & $\begin{array}{l}\text { Upper } \\
\text { Miocene }\end{array}$ \\
\hline $\begin{array}{l}\text { Proantigonia } \\
\text { radobojana }\end{array}$ & $\begin{array}{c}22 \\
(10+12)\end{array}$ & III, 19-21 & IX, 19-21 & Anterior & $6^{\text {th }}$ & $1.9-2.4$ & $1.7-2.7$ & $0.7-1.3$ & $14-17$ & $\begin{array}{l}\text { Upper } \\
\text { Miocene }\end{array}$ \\
\hline $\begin{array}{l}\text { Eoantigonia } \\
\text { veronensis }\end{array}$ & $\begin{array}{c}22 \\
(10+12)\end{array}$ & III, 21 & IX, 22 & On the line & $6^{\text {th }}$ & 2.8 & 1.1 & 0.4 & - & $\begin{array}{l}\text { Lower } \\
\text { Eocene }\end{array}$ \\
\hline
\end{tabular}

morphology of that of $C$. aper and Antigonia capros (Rosen 1984), rather than the antero-dorsal morphology of this vertebra in zeiforms (see Tyler et al. 2003). Caprosimilis carpathicus gen. et sp. nov. has three supernumerary spines (the first is tiny) on the first radial of the anal fin, while zeiforms and caproids have only two. Probably the pattern with a small anterior anal spine is plesiomorph and found in many higher acanthopterygians.

The pelvis was oriented at an angle of 45 degrees or less in C. carpathicus gen. et sp. nov., as in Capros (Zehren, unpublished MS) and other caproids (Baciu et al. 2005a, b), including, the very deep-bodied Antigonia (Starks 1902, Zehren 1987, Świdnicki 1988). A similar orientation is present in the moderately deep-bodied zeiform Zenopsis (Zeidae, Baciu et al. 2005c). The rather deep-bodied Protozeus also has such a low-angled orientation of the pelvis (see Bonde 1987, Tyler et al. 2000, Bonde et al. 2008). In most of the deep-bodied zeiforms (see Tyler et al. 2003) and in the oldest known zeiform, Cretazeus (Tyler et al. 2000), the position of the pelvis is nearly vertical.

Caprosimilis carpathicus gen. et sp. nov. shares many osteological characters and some measurements with Lower Oligocene Proantigonia cosmovici, Capros caprosoides and $C$. rhenanus. We consider it is close relative of those taxa.

There are no Early Cretaceous well-preserved skeletons of possible ancestors or relatives of zeomorphs, such as gadiforms or percomorphs. Spenocephalids from the
Late Cretaceous such as Xenyllion (see Steward 1996, Newbrey et al. 2013) could be considered as ancestral forms. Only some perciforms are known in the latest Cretaceous (see Sorbini \& Bannikov 1991, Patterson 1993, Arratia et al. 2004), but they seem not to be closely related with $C$. carpathicus gen. et sp. nov.

Grande et al. (2013) proposed morphological characters that unite the clade consisting of zeiforms + Stylephorus + gadiforms. One character, first neural arch and spine associated with neurocranium is present in C. carpathicus gen. et sp. nov. and is also present in Antigonia, Acanthonemus, Eoantiginia, Proantigonia, extant and extinct species of Capros. Three characters: loss of the haemal arch of preural centrum 1, fusion of hypurals 1 and 2, lack of an autogenous first uroneural are absent in C. carpathicus gen. et sp. nov. It has the haemal arch (parhypural) articulating with preural centrum $1+$ ural centrum 1, not fused hypurals 1 and 2 and autogenous first and second uroneural. Three characters: gadoid notch, single hyomandibular condyle, fusion of upper hypurals with each other and with ural centrum 2 are not possible to determine on our specimen. Grande et al. (2013) proposed also morphological characters that unite Zeiformes. First proximal dorsal radial contacting first neural arch and spine is present in C. carpathicus gen. et sp. nov. A reduced metapterygoid probably is present. Loss of wide separation of exoccipital facets, unbranched dorsal and anal rays, unbranched pectoral rays are not possible to determine on our specimen. 


\section{Conclusions}

The phylogenetic analysis of morphological characters shows that $C$. carpathicus gen. et sp. nov. forms a clade with Capros or is in a sister-group relationship with the clade formed by Capros and Antigonia. Our analysis indicates that two synapomorphies can support a clade formed by $C$. carpathicus gen. et sp. nov., Acanthonemus, caproids, and Zorzinichthys. Caprosimilis carpathicus gen. et sp. nov. is a close relative of Lower Oligocene Proantigonia cosmovici, Capros caprosoides and $C$. rhenanus known from Paratethys.

\section{Acknowledgement}

We are very grateful to James C. Tyler (Washington) for discussions on the anatomy and phylogeny of zeomorpha, review and comments that have led to improvements of the manuscript and language. We also thank two anonymous reviewers for constructive comments on an earlier version of the manuscript. The specimen was collected by Tomasz Praszkier. Marian Dziewiński made photos and Aleksandra Holda-Michalska helped with drawings. This work was supported in part by founds of the Faculty of Geology, University of Warsaw, DSM Grant, 102908 to M.B.-W. and N.B. is very thankful to the Fur Museum (Muserum Salling) for financial support to several visits in Warsaw and journeys in 2013 and 2014 to Verona, and he is very grateful for the hospitality he has received from the Polish Academy of Sciences, and for providing him with study fascilities. N.B. is grateful to Anna Vaccari and Roberto Zorzin, Museo Civico di Storia Naturale, Verona, Italy for access to specimens of Acanthonemus and other Bolca fishes.

\section{References}

Arratia, G., López-Arbarello, A., Prasad, G.V.R., Parmar, V. \& KRIWET, J. 2004. Late Cretaceous-Paleocene percomorphs (Teleostei) from India - early radiation of Perciformes, 635-663. In Arratia, G., Wilson, M.V.H. \& Cloutier, R. (eds) Recent Advances in the Origin and Early Radiation of Vertebrates. Verlag Dr. Friedrich Pfeil, München.

Baciu, D.-S., Bannikov, A.F. \& SAntini, F. 2005a. A new species of Caproidae (Acanthomorpha, Teleostei) from the Messinian (upper Miocene) of Oran (Algeria). Geodiversitas 27(3), 381-390.

BACIU, D.-S., BANNiKov, A.F. \& TYleR, J.C. 2005b. Revision of the fossil fishes of the family Caproidae (Acanthomorpha). Miscellanea Paleontologica, Studi e Ricerche sui Giacimenti Terziari di Bolca 11, 7-74.

Baciu, D.-S., Bannikov, A.F. \& TYler, J.C. 2005c. Revision of the fossil fishes of the family Zeidae (Zeiformes). Bolletino del Museo Civico di Storia Naturale di Verona (Geologia, Paleontologia, Preistoria) 29, 95-118.

BanniKov, A.F. 1991. On the systematic position of the family Caproidae with reference to the Eocene genus Acanthonemus. Voprosy ikhtiologii 3, 179-188. [in Russian; translated in Journal of Ichthyology 31, 47-58]

BANNIKOv, A.F. \& TYLER, J.C. 1999. Sorbinicapros, a new second taxon of the caproid-related fish family Sorbinipercidae, from the Eocene of Monte Bolca, Italy. Studi e Ricerche sui Giacimenti Terziari di Bolca, Museo Civico di Storia Naturale di Verona 8, 129-142.

Bieńkowska-Wasiluk, M. 2010. Taphonomy of Oligocene teleost fishes from the Outer Carpathians of Poland. Acta Geologica Polonica 60(4), 479-533.

BlainvilLe, H.M.D. DE 1818. Des ichthyolites du Monte Bolca, ou Vestena Nuova dans le Veronais, 334-361. In: Nouveau dictionnaire d'histoire naturelle appliquée aux arts, à l'agriculture, à l'economie rurale et domestique, à la medecine 27. Déterville, Paris.

Blot, J. 1969. Les poissons fossiles du Monte Bolca. Classé jusqu'ici dans les familles des Carangidae, Menidae, Ephippidae, Scatophagidae. Studi e Ricerche sui Giacimenti Terziari di Bolca, Museo Civico di Storia Naturale di Verona, Memorie Fuori Serie No. 2(1), 1-525.

Bonde, N. 1987. Moler - its Origin and its Fossils Especially Fishes. 52 pp. Skamol, Nykøbing Mors, Denmark.

Bonde, N. 1997. A distinctive fish fauna in the basal ash-series of the Fur/Ølst Formation (U. Paleocene, Denmark). Aarhus Geoscience 6, 33-48.

Bonde, N.C \& Christensen, E.F. 1991. "Det første danekræ - en ganske lille fisk". Varv 1, 12-14.

Bonde, N., Andersen, S., Hald, N. \& Jakobsen, S.L. 2008. Danekrä - Denmark's Best Fossils. 224 pp. Gyldendal, København. [in Danish]

Bonde, N., Madsen, H., Schultz, B., Sylvestersen, R. \& JAKobSEn, S.L. 2011. Mo-clay in North Jutland - diatomite and fossils. Dansk Naturhistorisk Forening 19-20 (for years 2008-2010), 25-40. [in Danish]

Chen, W.J., Bonillo, C. \& Lecointre, G. 2003. Repeatability of clades as a criterion of reliability: a case study for molecular phylogeny of Acanthomorpha (Teleostei) with larger number of taxa. Molecular Phylogenetics and Evolution 26, 262-288. DOI 10.1016/S1055-7903(02)00371-8

Dettaï, A. \& Lecointre, G. 2008. New insights into the organization and evolution of vertebrate IRBP genes and utility of IRBP gene sequences for the phylogenetic study of the Acanthomorpha (Actinopterygii: Teleostei). Molecular Phylogenetics and Evolution 48, 258-269.

DOI 10.1016/j.ympev.2008.04.003

Gradstein, F., OgG, J. \& Smith, A. 2004. A Geologic Time Scale 2004. 589 pp. Cambridge Press, Cambridge. DOI 10.4095/215638

Grande, T., Borden, W.C. \& SMith, W.L. 2013. Limits and relationships of Paracanthopterygii: A molecular framework for evaluating past morphological hypotheses, 385-418. In Arratia, G., Schultze, H.-P. \& Wilson, M.V.H. (eds) Mesozoic Fishes 5 - Global Diversity and Evolution. Verlag Dr. Friedrich Pfeil, München.

Greenwood, P.H., Rosen, D.E., Weitzman, S.H. \& Myers, G.S. 1966. Phyletic studies of teleostean fishes, with a provisional classification of living forms. Bulletin of the American Museum of Natural History 131(4), 339-456.

GolobofF, P.A., Farris, J.S. \& Nixon, K.C. 2008. TNT, a free program for phylogenetic analysis. Cladistics 24, 774-786. DOI 10.1111/j.1096-0031.2008.00217.x

JERZMAŃSKA, A. 1968. Ichtyofaune des couches à ménilite (flysch des Karpathes). Acta Palaeontologica Polonica 13(3), 379-488.

JerZmańsKa, A. \& KotlarcZyK, J. 1968. Ichthyofaunal assemblages in Menilite Beds of the Carpathians as indicators of 
sedimentary environment. Rocznik Polskiego Towarzystwa Geologicznego (Annales de la Société Géologique de Pologne) 38(1), 39-66. [in Polish with English summary]

Johnson, G.D. \& Patterson, C. 1993. Percomorph phylogeny: a survey of acanthomorphs and a new proposal. Bulletin of Marine Sciences 52, 554-626.

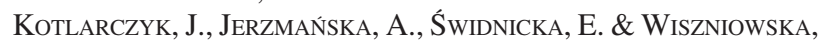
T. 2006. A framework of ichthyofaunal ecostratigraphy of the Oligocene-early Miocene strata of the Polish Outer Carpathian basin. Annales Societatis Geologorum Poloniae 76(1), 1-111.

Li, B., Dettaï, A., Cruaud, C., Couloux, A., DesoutterMeniger, M. \& Lecointre, G. 2009. RNF213, a new nuclear marker for acanthomorph phylogeny. Molecular Phylogenetics and Evolution 50(2), 345-363. DOI 10.1016/j.ympev.2008.11.013

Miya, M., TAKeshima, H., Endo, H., Ishiguro, N.B., Inoue, J.G., Mukai, T., Satoh, T.P., Yamaguchi, M., Kawaguchi, A., Mabuchi, K., Shirai, S.M. \& Nishida, M. 2003. Major patterns of higher teleostean phylogenies: a new perspective based on 100 complete mitochondrial DNA sequences. Molecular Phylogenetics and Evolution 26, 121-138. DOI 10.1016/S1055-7903(02)00332-9

MedizZA, F. 1975. Il nannoplancton calcareo della Pesciara di Bolca (Monti Lessini). Studi e Ricerche sui Giacimenti Terziari di Bolca 2, 433-444.

Near, T.J., Dornburg, A., Eytan, R.I., Keck, B.P., Smith, W.L., Kuhn, K.L., Moore, J.A., Price, S.A., Burbrink, F.T., Friedman, M. \& Wainwright, P.C. 2013. Phylogeny and tempo of diversification in the superradiation of spiny-rayed fishes. Proceedings of the National Academy of Sciences of the United States of America (PNAS) 110, 12738-21743. DOI 10.1073/pnas. 1304661110

Nelson, J.S. 2006. Fishes of the world. $4^{\text {th }}$ edition. 601 pp. John Wiley and Sons, Inc., New York.

Newbrey, M.G., Murray, A.M., Wilson, M.V.H., Brinkman, D.B. \& Neuman, A.G. 2013. A new species of the paracanthopterygian Xenyllion (Sphenocephaliformes) from the Mowry Formation (Cenomanian) of Utah, USA, 363-384. In Arratia, G., Schultze, H.-P. \& Wilson, M.V.H. (eds) Mesozoic Fishes 5 - Global Diversity and Evolution. Verlag Dr. Friedrich Pfeil, München.

Nolf, D. \& TYleR, J.C. 2006. Otolith evidence concerning interrelationships of caproid, zeiform and tetraodontiform fishes. Bulletin de l'Institut Royal des Sciences Naturelles de Belgique, Biologie 76, 147-189.

Papazzoni, C.A. \& Trevisani, E. 2006. Facies analysis, palaeoenvironmental reconstruction, and biostratigraphy, of the "Pesciara di Bolca" (Verona, northern Italy): an early Eocene Fossil-Lagerstätte. Palaeogeography, Palaeoclimatology, Palaeoecology 242(1-2), 21-35. DOI 10.1016/j.palaeo.2006.05.011

Patterson, C. 1993. An overview of the early fossil record of the acanthomorphs. Bulletin of Marine Sciences 52, 29-59.

Patterson, C. \& Rosen, D.E. 1977. Review of ichthyodectiform and other Mesozoic teleost fishes and the theory and practice of classifying fossils. Bulletin of the American Museum of Natural History 158, 81-172.

Radwańska, U. 1992. Fish otoliths in the Middle Miocene (Badenian) deposits of southern Poland. Acta Geologica Polonica 42(3-4), 141-328.

Rosen, D.E. 1984. Zeiforms as primitive plectognath fishes. American Museum Novitates 2782, 1-45.
STARKS, E.C. 1902. The relationship and osteology of the caproid fishes or Antigoniidae. Proceedings of The United States $\mathrm{Na}$ tional Museum 25, 565-572.

DOI 10.5479/si.00963801.25-1297.565

Sorbini, L. 1983. La Collezione Baja di Pesci e Piante Fossili di Bolca con Descrizione di Nuovi Generi e Nuove Specie. 116 pp. Museo Civico di Storia Naturale, Verona.

Sorbini, L. \& BotturA, C. 1988. Antigonia veronensis, an Eocene caproid from Bolca. Bollettino del Museo Civico di Storia Naturale di Verona 14, 255-269.

Sorbini, L. \& Bannikov, A.F. 1991. The Cretaceous fishes of Nardo. $2^{\circ}$. An enigmatic spiny rayed fish. Bollettino della Società Paleontologica Italiana 30(2), 239-250.

STEWART, J.D. 1996. Cretaceous acanthomorphs of North America, 383-394. In Arratia, G. \& Viohl, G. (eds) Mesozoic fishes - systematics and paleoecology. Proceedings of the international meeting, Eichstätt, Germany, 1993. Verlag Dr. Friedrich Pfeil, München.

Stiassny, M.L. \& Moore, J.A. 1992. A review of the pelvic girdle of acanthomorph fishes, with comments on hypotheses of acanthomorph interrelationships. Zoological Journal of the Linnean Society 104, 209-242.

DOI 10.1111/j.1096-3642.1992.tb00923.x

ŚwidNICKI, J. 1988. Juveniles of some Oligocene Antigonia (Caproidae, Teleostei) from the Polish Carpathians. Acta Palaeontologica Polonica 33(3), 249-258.

TYLER, J.C. 1998. A new family for a long known but undescribed acanthopterygian fish from the Eocene of Monte Bolca, Italy: Sorbiniperca scheuchzeri gen. \& sp. nov. Eclogae Geologicae Helvetiae 91, 521-540.

TYleR, J.C. \& Bannikov, A.F. 2002. A new genus and species of deep-bodied perciform fish (Teleostei) from the Eocene of Monte Bolca, Italy, representing a new family, the Zorzinichthyidae, related to the caproid- and sorbinipercid-like clades. Studi e Ricerche sui Giacimenti Terziari di Bolca, Museo Civico di Storia Naturale di Verona 9, 23-35.

Tyler, J.C., Bronzi, P. \& Ghiandoni, A. 2000. The Cretaceous fishes of Nardo 11. A new genus and species of Zeiformes, Cretazeus rinaldii, the earliest record for the order. Bolletino del Museo Civico di Storia Naturale di Verona 24, 11-28.

Tyler, J.C., O’Toole, B. \& Winterbottom, R. 2003. Phylogeny of the genera and families of zeiform fishes, with comments on their relationships with tetraodontiforms and caproids. Smithsonian Contributions to Zoology 618, 1-110.

DOI 10.5479/si.00810282.618

Tyler, J.C. \& SAntini, F. 2005. A phylogeny of the fossil and extant zeiform-like fishes, Upper Cretaceous to Recent, with comments on the putative zeomorph clade (Acanthomorpha). Zoologica Scripta 34, 157-175.

DOI 10.1111/j.1463-6409.2005.00180.x

TYLER, J.C. \& SORBINI, L. 1996. New superfamily and three new families of tetraodontiform fishes from the Upper Cretaceous: the earliest and most morphologically primitive plectognaths. Smithsonian Contributions to Paleobiology 82, 1-59. DOI 10.5479/si.00810266.82.1

WiLEY, E.O. \& JoHNSON, G.D. 2010. A teleost classification based on monophyletic groups, 123-182. In NeLson, J.S., SchUlze, H.-P. \& WiLson, M.V.H. (eds) Origin and Phylogenetic Interrelationships of Teleosts. Verlag Dr. Friedrich Pfeil, München.

ZeHren, J. 1987. Osteology and evolutionary relationships of the boarfish genus Antigonia (Teleostei: Caproidae). Copeia 3, 564-592. DOI 10.2307/1445651 